\title{
Article \\ Planning behind Closed Doors: Unlocking Large-Scale Urban Development Projects Using the Stakeholder Approach on Tenerife, Spain
}

\author{
Marcus Hübscher (D)
}

check for updates

Citation: Hübscher, M. Planning behind Closed Doors: Unlocking Large-Scale Urban Development Projects Using the Stakeholder Approach on Tenerife, Spain. Land 2022, 11, 390. https://doi.org/ 10.3390/land11030390

Academic Editor: José Ruiz Chico

Received: 10 February 2022

Accepted: 3 March 2022

Published: 7 March 2022

Publisher's Note: MDPI stays neutral with regard to jurisdictional claims in published maps and institutional affiliations.

Copyright: (C) 2022 by the author. Licensee MDPI, Basel, Switzerland. This article is an open access article distributed under the terms and conditions of the Creative Commons Attribution (CC BY) license (https:// creativecommons.org/licenses/by/ $4.0 /)$.
Institute of Urban Development and Construction Management, University of Leipzig, 04315 Leipzig, Germany; huebscher@wifa.uni-leipzig.de

\begin{abstract}
Santa Cruz Verde 2030 is an inner-city megaproject that will transform the local oil refinery into an urban neighborhood in Santa Cruz de Tenerife, Spain. The project is expected to reconfigure Santa Cruz's tourism model significantly, while applying rather undemocratic planning practices. This paper explores Santa Cruz Verde 2030, focusing on the perception of local stakeholders. My research builds on 18 qualitative interviews with planning authorities, the city's mayor, political parties, experts from the real estate sector and residents. I identify a large perception gap among the interviewees. While the project's initiators praise the participatory process, other stakeholders feel neither informed nor integrated. In particular, the "behind closed doors" planning approach has provoked resentment among citizens. In contrast, the possible impact on tourism of the project has given rise to less discussion. This contributes to the "stealthy" touristification strategy that has already transformed large areas of Santa Cruz's waterfront in past decades. Hence, this paper adds to the ongoing discussion on how to design megaprojects in a more sustainable way, for example, by ensuring political consensus and learning from former megaprojects.
\end{abstract}

Keywords: megaprojects; tourism; touristification; gentrification; planning; stakeholders; Santa Cruz de Tenerife; qualitative interviews

\section{Introduction}

Touristifying undiscovered areas is a highly conflictive process. This goes for landscapes close to nature [1,2], as well as for urban spaces [3,4]. The reasons for the recent "wave of touristification" [5] (p. 1) are manifold, but neoliberalism in general [6] and the emergence of platform economies in particular [7] are some of the main drivers. Additionally, many countries have (re)discovered tourism as an economic growth strategy, particularly after 2008's financial and economic crisis [5] (p. 1). This was particularly the case in Spain, which is the world's second largest tourist destination, with 83 million arrivals in 2018 [8]. In Spain, international visitor numbers grew by about $60 \%$ between 2008 and the outbreak of the COVID-19 pandemic in 2019 [9].

While touristification through Airbnb and other similar platforms is a rather stealthy process [10], some city governments are engaged more actively in promoting tourism. In this respect, inner-city megaprojects have been used in countless cases to reposition cities in the global urban hierarchy, upgrade their image, and attract investment, new inhabitants, and tourists [11,12]. This new generation of megaprojects [13] poses major challenges to cities and residents, as well as the local planning systems. Decision-makers are quite creative in either avoiding civic participation or enabling a very limited scope thereof, where no true integration of local stakeholders is permitted [14,15]. Simultaneously, the stakeholder approach is also neglected in research [16], although it is a valuable means to increase both sustainability and the "right" to these projects, as seen from the inhabitants' perspective.

This paper focuses on Santa Cruz Verde 2030 in Tenerife, known as Spain's "largest urbanistic operation" [17]. Santa Cruz, the capital of Tenerife with about 200,000 inhabi- 
tants [18], already experienced the impacts of an urbanistic megaproject during the 1990s (Cabo-Llanos Plan). Here, one third of an inner city oil refinery became derelict and was transformed into a new neighborhood, while an adjacent working class quarter was displaced $[19,20]$.

In June 2018, the owner of the refinery (the Spanish oil company CEPSA) and the city's mayor announced Santa Cruz Verde 2030. This new megaproject will transform the remaining industrial plant into a mixed-use area (576,000 square meters) with green spaces (41\%), residential areas (21\%), and urban hotels (10\%) [21]. Apart from that, the megaproject aims to reconfigure the urban mobility systems, for example by providing access to the planned railway infrastructure on Tenerife [22], and a bicycle lane between the northern and southern peripheries of the city [21]. The development program puts a clear emphasis on a sustainable transition, promising the use of renewable energies, smart technologies, and civic participation "in every phase of the development" [21] (p. 6).

However, Santa Cruz Verde 2030 is expected to undergo a considerable touristification process, as it fosters the city's transition towards a service-oriented economy. The megaproject (a) contains the city's first urban beach and intends to reshape Santa Cruz' relationship with the sea, and (b) almost doubles the number of hotel beds in the city [23] in an area where neither hotels nor short-term rentals are currently present [24]. Although Santa Cruz is a nontouristic city [20], it is the capital of Spain's third most visited tourist region, namely the Canary Islands [25] (see Figure 1).

Exploring the megaproject Santa Cruz Verde 2030 adds to the understanding of the dynamics in potential tourist areas that are not yet exploited. This is particularly compelling in the context of touristic islands, where intensive conflicts between land and mass-tourism exists [26] (p. 52). On numerous islands, these conflicts become evident due to a shortage of land, high-intensity uses, and the dependency on tourism that leads to higher vulnerabilities [27]. This goes for the Canary Islands and Tenerife in particular, where tourism is seen as one reason for the ongoing "commodification of land" [28] (p. 249), and the existing tensions in local housing markets [29]. Hence, applying the so-called "islandscape" as a lens that permits to explore "the local, national, and global [ . . ] while still acknowledging the importance of the island" [30] is a fruitful approach to this case study-and one which helps to explore the relationship between land and tourism in Santa Cruz de Tenerife.
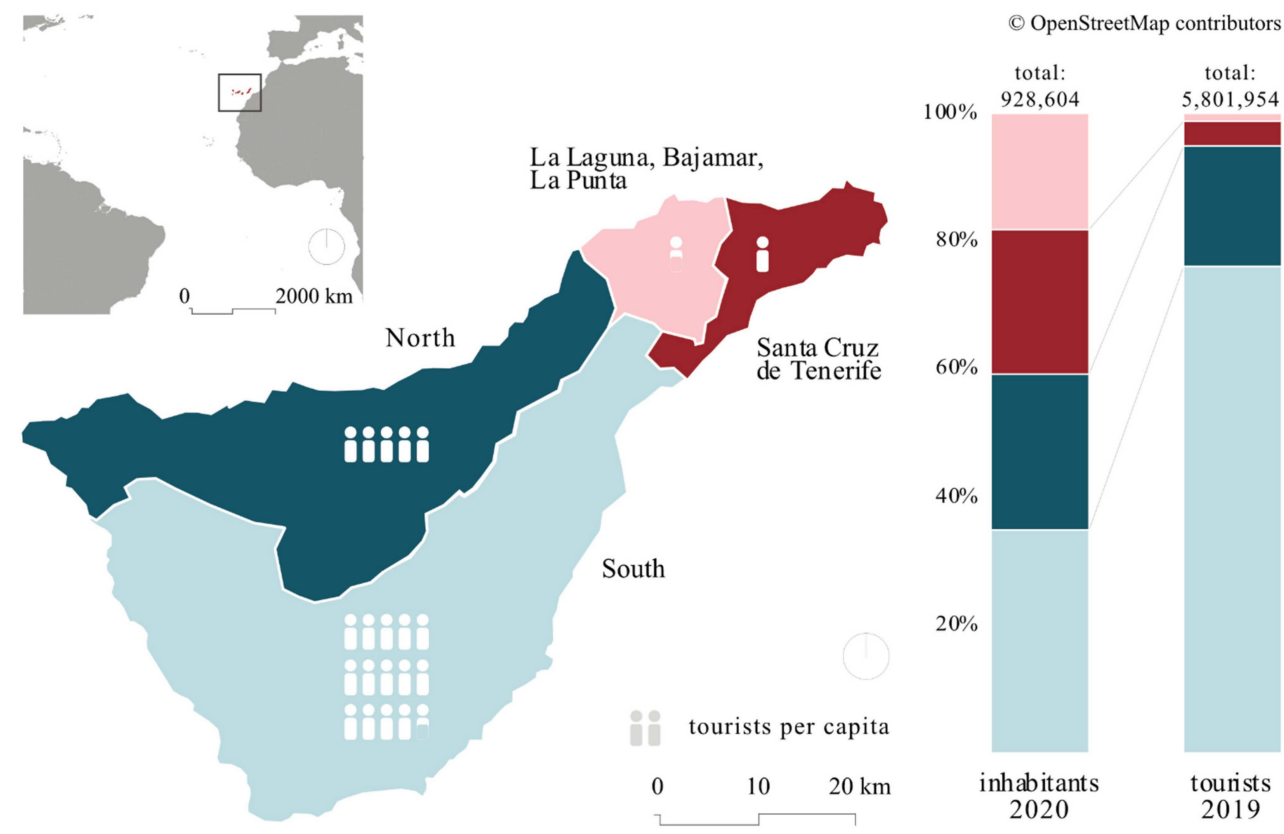

Figure 1. Tourist and population numbers in Tenerife. Own elaboration based on Cabildo de Tenerife [31], Turismo de Tenerife [32] and Open Street Map and Geofabrik GmbH [33]. 
Hence, the objective of this paper is to explore how Santa Cruz Verde 2030 is perceived by local stakeholders. I investigate both the perceptions of the planning process and the conceptual elements of the megaproject by means of 18 qualitative interviews. This will contribute to a better understanding of how this touristically undeveloped urban land is being transformed within a tourist region, and how the process is evaluated. I will uncover a large perception gap between different stakeholders, which manifests in contradicting narratives about the project. I identify at least three conflictive areas, namely, planning, possible impacts, and the motivations behind the project. In contrast, the concept of the megaproject causes less controversy. This supports the argument that the highly touristic regional setting, in which Santa Cruz is embedded, contributes to a less critical attitude towards tourism. Apart from that, exploring this case reveals who actually has the right to this megaproject, and who has not.

The paper is structured as follows. Section 2 presents the theoretical framework and will firstly describe the role of tourism in megaprojects. Secondly, the focus is put on stakeholders in large-scale urban development projects. Section 3 discusses the methods and outlines the first quantitative approach to the material. Section 4 presents the results and is divided into several subsections, which deal with the perceptions of stakeholders with regard to planning and concept. The final section concludes, and asks for and by whom Santa Cruz Verde 2030 is being shaped.

\section{Tourism and Megaprojects: The Stakeholders' Perspectives}

\subsection{Unleashing Tourism through Megaprojects}

Urban tourism might be regarded as "underexplored" [34] (p. 1305) in academia, but it has been discussed as a growth strategy from an entrepreneurial perspective for a long time [35] (p. 9). In this sense, "tourist bubbles are carved out of areas that otherwise would be hostile to or inconvenient for tourists", following Judd and Fainstein's concept of converted cities [36] (p. 266). However, seen from the consumption side, urban tourists themselves are continuously in search of "authenticity" [37], for example, in ethnic neighborhoods [38], or other urban places "off the beaten track" [34] (p. 1311). It is this new urban tourism that describes an increasing contact between visitors and the "mundane life" of ordinary inhabitants [39] (p. 276).

In research, "there is a whole genre of travel and tourism literature dedicated to the "undiscovered"' [40] (p. 288). I frame the discovering of such originally nontouristic spaces as touristification $[7,41]$, because it "refers to the complex processes of territorial transformation brought about by tourism on a determined geographical space" [42] (p. 3). On the one hand, this process might take place gradually, as described in Gotham's concept of tourism gentrification [43], or due to the spatial proliferation of short-term rentals, which increasingly move to neighborhoods outside the touristic center [24,44]. On the other hand, touristification can also be triggered by large-scale projects transforming an important part of the city, such as waterfronts or brownfield sites [14,45,46]. Spain is certainly the most studied country when it comes to large-scale projects that are linked to gentrification and touristification processes [47], with well-known examples in Valencia (City of Arts and Sciences; [48]) and Bilbao (Guggenheim Museum; [49]).

Large-scale projects are seen as a means to climb the global urban hierarchy and boost a city's opportunities in terms of urban competition [50,51] (p. 21), which turns megaprojects into one of the most visible symbols in the neoliberal city [13,52]. Within such megaprojects, tourism is often one element in a broad mix of uses [14,46], or can even be the decisive function [53]. At best, tourism helps to foster economic growth and improve the city's image [48] (p. 137); [54]. However, pushing urban spaces towards tourism has a price. It provokes a general intensification of land uses [55], community conflicts [56], rising costs of living [57] and the displacement of inhabitants or other functions and practices, also known as gentrification [58]. Some authors even see tourism as one factor that undermines the right to the city, in Lefebvre's sense, as it links "tourism overcrowding to place alienation and unjust 
socio-spatial processes" [59] (p. 172). Consequently, one of the central issues is to ask "whose right to the city" it actually is [60] (p. 1)—and put the focus on the local stakeholders.

In tourism research, this turn towards stakeholders and their perceptions is omnipresent. This tendency is observed in other scientific studies [4,61], but also in current reports by the World Tourism Organization [62]. It comes as no surprise that stakeholder approaches are reflected in concepts such as touristification, and help to understand "different stakeholders and factors propelling the transition to an economy based on tourism activities" [42] (p. 2). Even within newer concepts such as overtourism, stakeholders' perceptions are the predominant perspective [63]. On that basis, I regard the question of who has the right to the city as one of the more striking queries in this study. In the following paragraph, I will further explore the stakeholder approach, linking it to megaproject theory as the conceptual framework of this case.

\subsection{Stakeholder Approaches to Megaprojects}

There is a variety of typologies of megaprojects, such as power plants, infrastructure projects, as well as new built neighborhoods and mega events [64,65] (p. 4). Accordingly, proposals to define megaprojects are manifold, but "most are inexact and tied to specific project types" [66] (p. 15). As for this case study, I apply a qualitative understanding and define megaprojects as entities that reshape the urban fabric in various ways $[50,66]$ (p. 15).

Megaprojects are studied from different angles, such as management [67], the evaluation of potential impacts [48], and social contestation [68]. In the field of planning, important contributions have been made by Flyvbjerg [69,70] and Del Cerro Santamaría [71]. Despite the abundant literature in this field, the fact that "no one is learning from past mistakes, or no one wants to learn" [72] (p. 20) speaks for itself. It is particularly the relation between local stakeholders and the projects that provokes conflicts, for example, due to participation being restricted $[11,15]$.

This stands in stark contrast to normative policy documents, where the importance of enabling sustainable and participative planning processes is one major claim. This is reflected on different institutional scales, such as in the 17 sustainability goals of the United Nations [73] (p. 8), in the New Leipzig Charter 2021 of the European Union [74] (p. 6), or on national levels such as in the "Spanish Urban Agenda" [75] (p. 264).

Research on planning has traditionally put emphasis on the stakeholders that are in charge $[76,77]$ (p. 289). However, secondary stakeholders are rather underexplored [16] (p. 1537). They "do not have a formal contractual bond with the project" [78] (p. 3), although they might have an influence, and will certainly feel the impacts of the megaproject. This is a fact that many scientific contributions neglect [79] (p. 63); [80]. There are a growing number of studies, though, that focus on these secondary stakeholders in their analysis $[46,81,82]$. Even megaproject leaders increasingly acknowledge the relevance of a broader set of stakeholders [77] (p. 289).

Addressing stakeholders' perceptions is one of the first steps in enabling participation, which is regulated via formal and informal planning instruments in many countries around the globe [83]. With regard to large-scale projects, two problems exist. Firstly, the question remains of how much true participation is permitted. Secondly, megaprojects are established as an exceptional planning instrument [50] (p. 71); [84], with new rules and usually little space for participation [85] (p. 61). In this sense, megaprojects privatize urban planning [86] (p. 78) and must finally be regarded as planning instruments themselves [87], which tend to avoid the established rules of participation $[14,65]$ (p. 6).

Hence, I regard large-scale projects as a decisive element when redefining the right to the city. In this context, we do not only have to question whether or not megaprojects contribute to "the fair and equitable distribution in space of socially valued resources" [88] during their planning phase. It is also the general notion of displacement or noninclusion as specific forms of spatial injustice that is "intrinsic to megaproject development" [66] (p. 15). To put it in Marcuse's words, I see the "involuntary confinement of any group to a limited space" [89] (p. 83) as a key aspect of spatial injustice, which is often provoked 
by exclusionary and elitist megaprojects [90]. The prevailing case study will focus on this question, and thus determine who are the "winners and losers" [66] (p. 23) in the megaproject process.

\section{Method and Material}

\subsection{Qualitative Interviews as Approach to the Case}

In order to collect local stakeholders' perceptions, I conducted qualitative (expert) interviews. This is not only the most used method when exploring case studies in the intertwined field of megaprojects, gentrification, and tourism [47] (p. 11); interviews also provide valuable insights into the underestimated field of stakeholder approaches [78] (p. 2).

In the case study, I identified potential interviewees based on the CABERNET stakeholder model [91], which considers groups from different fields. I regarded someone as an expert if this person was (a) a (primary) stakeholder within the megaproject Santa Cruz Verde 2030 (land owner or politician in charge), or (b) represented a relevant interest group within the urban society, which might be affected directly or indirectly by the project (secondary stakeholders such as community groups, developers, academics, professional advisors). I contacted the mayor and representatives of local parties, but also professional associations (see Table 1). They provided me with contacts of further stakeholders, such as local neighborhood associations snowball sampling, [92] (p. 50).

The interviews were conducted during three research stays in the field (summer 2019, spring 2020, summer 2020). In total, I conducted interviews with four primary (I2, I6, I13 and I18) and 14 secondary stakeholders, and I argue that is sufficient to display an important share of perspectives in the local discourse. The underlying criteria that I propose here is saturation, which is "met when the same information is heard repeatedly" [92] (p. 52). I conducted 14 interviews on Tenerife; 3 were done online via video-telephony. Only one interviewee (I18, CEPSA) insisted on answering my questions in written form.

The interviews were semi-structured by means of a guideline (Table 2). Some of these topics were expanded or cut down, adapting to the function and interest of each interviewee. Each conversation started with an informal part, wherein I introduced myself and explained the purpose of the interview and the research project, as well as data protection issues [92] (p. 53). All of the interviewees gave their consent for me to record the conversation.

In order to introduce a new topic, I stimulated the conversation with open questions first [93] (p. 39) (such as "How do you perceive the demolition of the oil refinery?"). In case the interviewees did not provide clear answers or when I had the feeling that there might be more information, I used more specific follow up questions [94] (p. 2962).

With regards to exploiting the material, I have applied a qualitative content analysis. The main objective here is to give the data a structure [95] (p. 440). I used codes as "smallest unit of data that is identified in the transcript" [92] (p. 58). To prepare the coding process, I relied on different phases. I first reread the interviews, familiarized myself with the material, and identified key information [96] (p. 363). As for the construction of the code system, I applied both inductive and deductive techniques. One section of categories was developed based on the material (inductive) [97]. Apart from that, I deduced the system of the main categories from theory [98] (p. 65). One part of the categories was thus related to the structure of the interview guideline. In this paper, I will not be able to analyze each of the interviews' themes. I rather focus on a selected number of aspects that are relevant to the research objective (Sections 1 and 2).

The presented research design entails limitations discussed in the literature $[99,100]$, such as for example the question of representativeness and generalizability [101]. I argue that the chosen interviewees are representative because they are either primary stakeholders within the megaproject or representatives of their respective institutions. Thus, they have relevant standpoints as they form part of the public discussion in the local media and elsewhere. Contrary to that, there are some voices that I as a researcher chose actively because I regard them as relevant, although they had not joined the public discussion so 
far, such as the neighbor (I12) or local researchers (I8 and I17). This reveals the obvious subjective position of the researcher and must be reflected critically.

Table 1. Overview of the interviews.

\begin{tabular}{|c|c|c|c|c|}
\hline No. & Organization/Institution & Function & Date & Place \\
\hline I1 & $\begin{array}{c}\text { Professional Association of Real } \\
\text { Estate Experts (APEI) }\end{array}$ & Regional delegate & 23.08.2019 & Office, Santa Cruz \\
\hline $\mathrm{I} 2$ & $\begin{array}{l}\text { Urban Planning office, town hall } \\
\text { Santa Cruz }\end{array}$ & Chief officer (Ciudadanos, C's) & 30.08 .2019 & Office, Santa Cruz \\
\hline I3 & Real estate agent & Self-employed & 02.09.2019 & Office, Santa Cruz \\
\hline $\mathrm{I} 4$ & $\begin{array}{c}\text { Local association of industrial } \\
\text { monument preservation }\end{array}$ & President & 04.09 .2019 & Public café, Santa Cruz \\
\hline I5 & $\begin{array}{l}\text { Local environmental association } \\
\text { (Ecologistas en Acción) }\end{array}$ & Representative & 12.09.2019 & $\begin{array}{l}\text { Public café, San } \\
\text { Cristóbal de la Laguna }\end{array}$ \\
\hline I6 & $\begin{array}{c}\text { Conservative Party (Partido } \\
\text { Popular, PP) }\end{array}$ & $\begin{array}{l}\text { Member of city parliament, } \\
\text { former chief officer in the urban } \\
\text { planning office }\end{array}$ & 09.03 .2020 & Public café, Santa Cruz \\
\hline I7 & Architect & $\begin{array}{c}\text { Self-employed, former president } \\
\text { of the Chamber of Architect of } \\
\text { the Canary Islands }\end{array}$ & 12.03 .2020 & Office, Santa Cruz \\
\hline I8 & $\begin{array}{l}\text { University of La Laguna, } \\
\text { Department of Geography }\end{array}$ & Geographer, research associate & 03.09 .2020 & $\begin{array}{c}\text { Office, San Cristóbal de } \\
\text { la Laguna }\end{array}$ \\
\hline I9 & Local journalist & $\begin{array}{l}\text { Self-employed, former head of a } \\
\text { local newspaper }\end{array}$ & 03.09 .2020 & Public café, Santa Cruz \\
\hline I10 & $\begin{array}{c}\text { Chamber of Architects of the } \\
\text { Canary Islands }\end{array}$ & Three employees/members & 07.09 .2020 & Public café, Santa Cruz \\
\hline I11 & $\begin{array}{l}\text { Labor Party (Partido Socialista } \\
\text { Obrero Español; PSOE) }\end{array}$ & $\begin{array}{l}\text { Member of the city parliament, } \\
\text { former chief officer in the urban } \\
\text { planning office }\end{array}$ & 09.09 .2020 & Online \\
\hline I12 & Buenos Aires Neighborhood & Neighbor & 10.09 .2020 & Public café, Santa Cruz \\
\hline I13 & Local government of Santa Cruz & Mayor & 11.09 .2020 & Town hall, Santa Cruz \\
\hline I14 & $\begin{array}{l}\text { Local neighborhood association } \\
\text { (preservation of history) }\end{array}$ & President and vice president & 11.09 .2020 & Online \\
\hline I15 & $\begin{array}{c}\text { Left-wing Party (Unidas } \\
\text { Podemos) }\end{array}$ & Member of the city parliament & 11.09 .2020 & Town hall, Santa Cruz \\
\hline I16 & $\begin{array}{l}\text { Local neighborhood association } \\
\text { of homeowners }\end{array}$ & President & 11.09 .2020 & Public café, Santa Cruz \\
\hline I17 & $\begin{array}{c}\text { Institute for History of Art, } \\
\text { University of La Laguna }\end{array}$ & Art historian, research associate & 17.09.2020 & Online \\
\hline I18 & CEPSA (oil refinery) & Representative & 26.01 .2021 & Written document \\
\hline
\end{tabular}

Still, I perceive the qualitative approach to space as a powerful tool to understand "people's experiences" [102] (p. 3) and how space is constructed [103] (p. 225), referring to both the built environment (such as the megaproject in this case), but also the social space between stakeholders. The small sample size proposed here facilitates "the researcher's close association with the respondents" [104] and thus enables me to explore the relation between tourism and land in this case study. 
Table 2. Guideline of the interviews.

Main Topics

Santa Cruz Verde 2030

Possible positive and negative effects
Subtopics

Public/political protest against the industrial activity Importance of the refinery for the city Demolition of the refinery

Relation between refinery and adjacent quarters

Opinion of the proposed uses and functions

General perception of the megaproject

Public discussion

Possible positive and negative effects

\section{Positive and negative impacts}

Housing market

Quality of life

Current status and future of adjacent neighborhoods (Buenos Aires, Chamberí, Cabo-Llanos)

\section{Planning}

Validity

Planning

Participation

Examples/references in the world

Transparency

\begin{tabular}{cc}
\hline Cabo-Llanos & $\begin{array}{c}\text { Transparency } \\
\text { Chase of deindustrialization/reasons } \\
\text { Conflicts in the neighborhoods } \\
\text { Learning process/lessons learnt } \\
\text { Monument preservation/el Tanque }\end{array}$ \\
Politics & $\begin{array}{c}\text { Change of government } \\
\text { Role of the two different governments } \\
\text { Political dimension of the project } \\
\text { Instrument for the election campaign }\end{array}$ \\
\hline
\end{tabular}

\subsection{Quantitative Analysis as First Analytical Step}

This paper presents a qualitative analysis. However, in order to become familiarized with the material and explore possible anomalies between the interviews [105] (p. 29), I used two quantitative tools provided by MAXQDA, namely, word cloud and code timeline.

I firstly drew a word cloud based on all 18 transcribed interviews (Figure 2). This word cloud shows terms that appeared at least 60 times each. I excluded filler words that were not content-related. Four aspects stand out here:

- Firstly, the words cluster around four main topics, namely, space, stakeholders, uses, and planning;

- Secondly, function-related aspects of the project, such as housing or green spaces, were not as present during the conversations as, for example, particular stakeholders or places. Tourism even played a minor role;

- Thirdly, primary stakeholders, such as CEPSA and the town hall, were named very often. However, the society in general, as a secondary stakeholder, gained the most hits;

- Fourthly, with regard to places, terms were used that refer to sites beside the megaproject itself. This is the case for "neighborhoods" in general, but also "center" and "Cabo-Llanos", which had the most hits of all the surrounding neighborhoods.

In the second step, I assessed the occurrences of codes quantitatively. Figure 3 reveals three main categories, which account for $88 \%$ of all codes. Planning was the most discussed topic, with more than $45 \%$ of all codes in this category. In contrast, the discussion of the megaproject per se, its concept, and future uses did not produce as much material $(21 \%)$. 


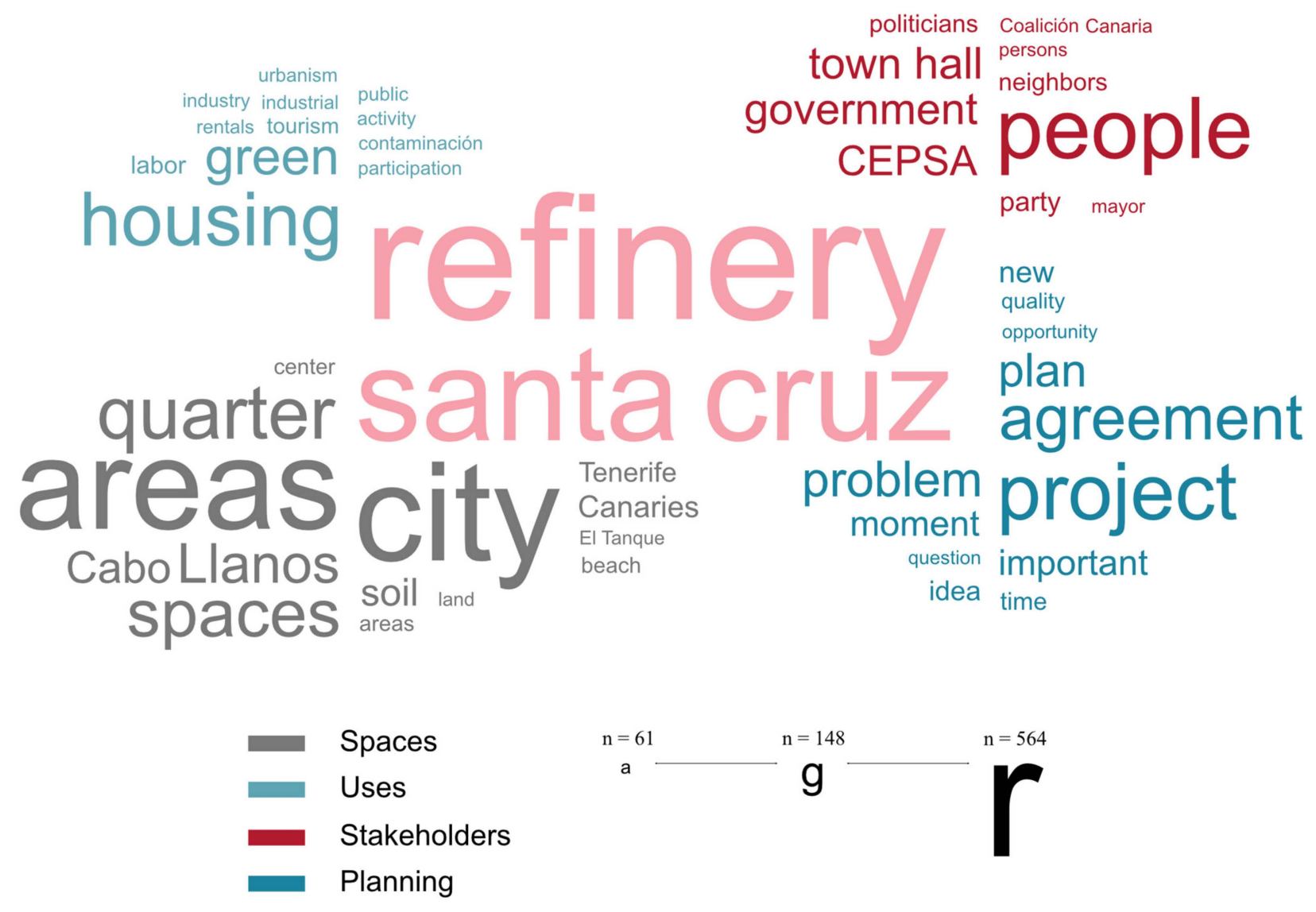

Figure 2. Word cloud based on the 18 transcribed interviews.

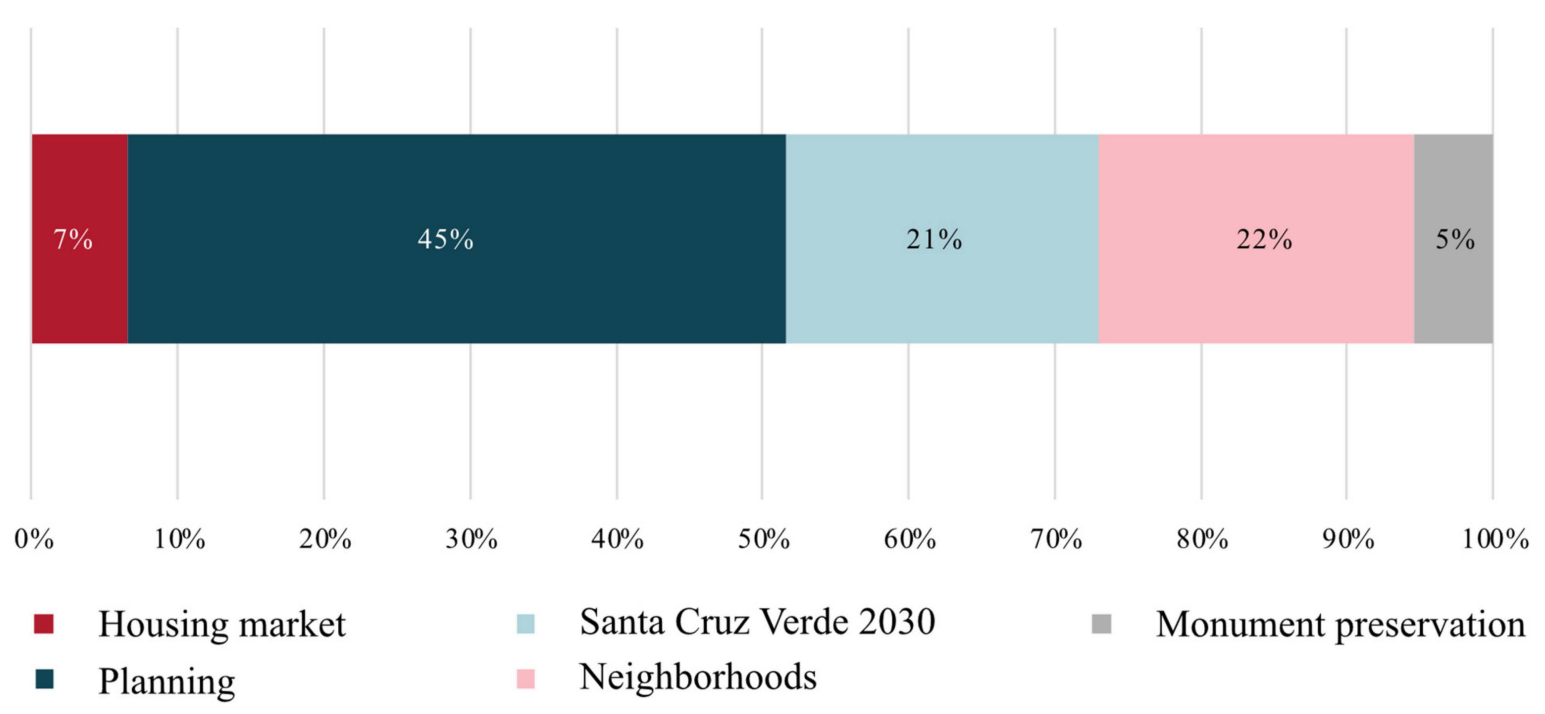

Figure 3. Top 5 main categories according to their numbers of codes.

A more detailed picture is given by Figure 4. Here, the codings are shown for each interview, revealing the differences and similarities between them:

- Firstly, planning (dark blue) and neighborhoods (light red) appeared in every interview, although to a different extent. In most of the interviews, one of these topics was the most dominant;

- Secondly, the discussion of the megaproject itself (contents) varied strongly between the interviews. Surprisingly, the conversations with the primary stakeholders focused 
less on contents, although I used comparable guidelines. Additionally, there are some longer sections in the transcripts wherein the megaproject concept was discussed in-depth, but it is striking that many interviewees referred to the project along the way (represented by the numerous short light-blue lines);

- Thirdly, Figure 4 shows that some interviews had a higher density of information, such as I1 or I11, while others contained large parts that were not coded because they were not considered to be relevant for this study (I14, I7).

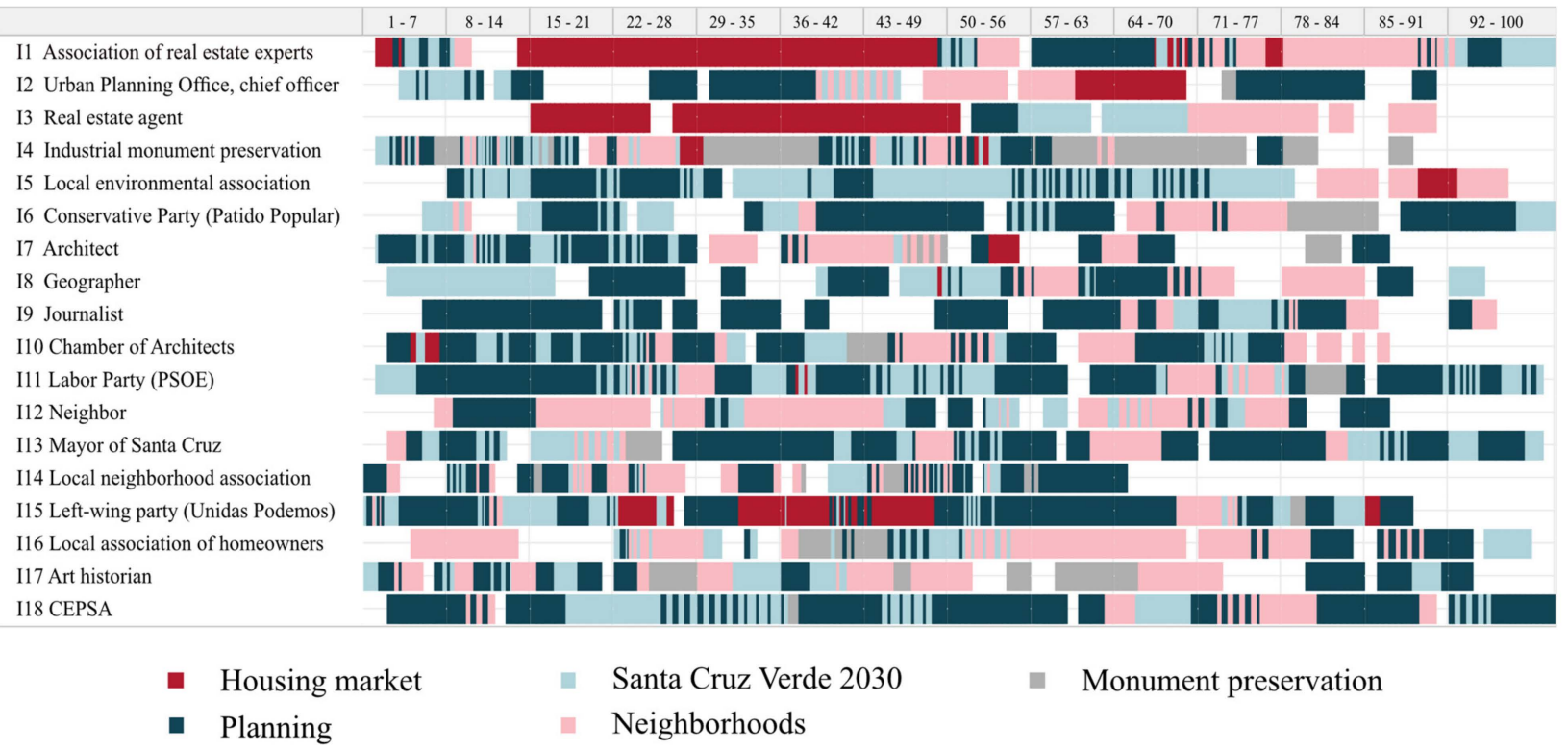

Figure 4. Timeline of each interview according to the codes assigned.

\section{Exploring Santa Cruz Verde 2030 through the Stakeholders' Lenses}

In this section, the findings of my case study are presented. I will put the focus on how Santa Cruz Verde 2030 is perceived by local stakeholders. My analysis will be presented in five sections, exploring the roles of different stakeholders (Section 4.1), the displacement process (Section 4.2), the role of tourism (Section 4.3), impacts (Section 4.4), and planning (Section 4.5).

\subsection{The Stakeholders and Their Roles}

This section explores the question of who is relevant in this new network shaped by the megaproject Santa Cruz Verde 2030. I see this as the first qualitative step in approaching the case, as it reveals the different stakeholders, their functions and their intentions, but also how others perceive them. Figure 5 illustrates the network based on the interviews. It shows a clear differentiation between those stakeholders managing the project (primary), located in the center of the inner circle, and those groups that are outside but still have relevant positions (secondary stakeholders).

There are two primary stakeholders, who not only initiated the project, but also currently manage the process, namely, CEPSA and the town hall of Santa Cruz. CEPSA is the current owner of the industrial plant, and is thus responsible for this initial phase of the project, for example, for the demolition of the plant and the negotiation process. However, the company sees its own involvement in the megaproject as temporally limited: "CEPSA is the current owner of the area, but the management of real estate is not our business" (I18: 34, CEPSA). Since 2011, CEPSA has belonged to an investment fund from Abu Dhabi (Mubadala Investment Company, [106]) with a diversified portfolio (energy infrastructure, real estate etc.; [107]. Most of the interviewees were aware of this new owner structure, mostly referring to them as Arab "sheiks" (I1: 6, Real estate association; I9: 45, Journalist; I08: 16, Geographer). What adds to the complexity here is that in 2019, the US American Carlyle Group acquired 37\% of CEPSA [107], but none of the local stakeholders knew about 
that. In fact, CEPSA itself revealed it in their interview, but remained rather vague about the role of Carlyle and Mubadala, which is to "focus on their strategy and guarantee that it is followed" (I18: 36).

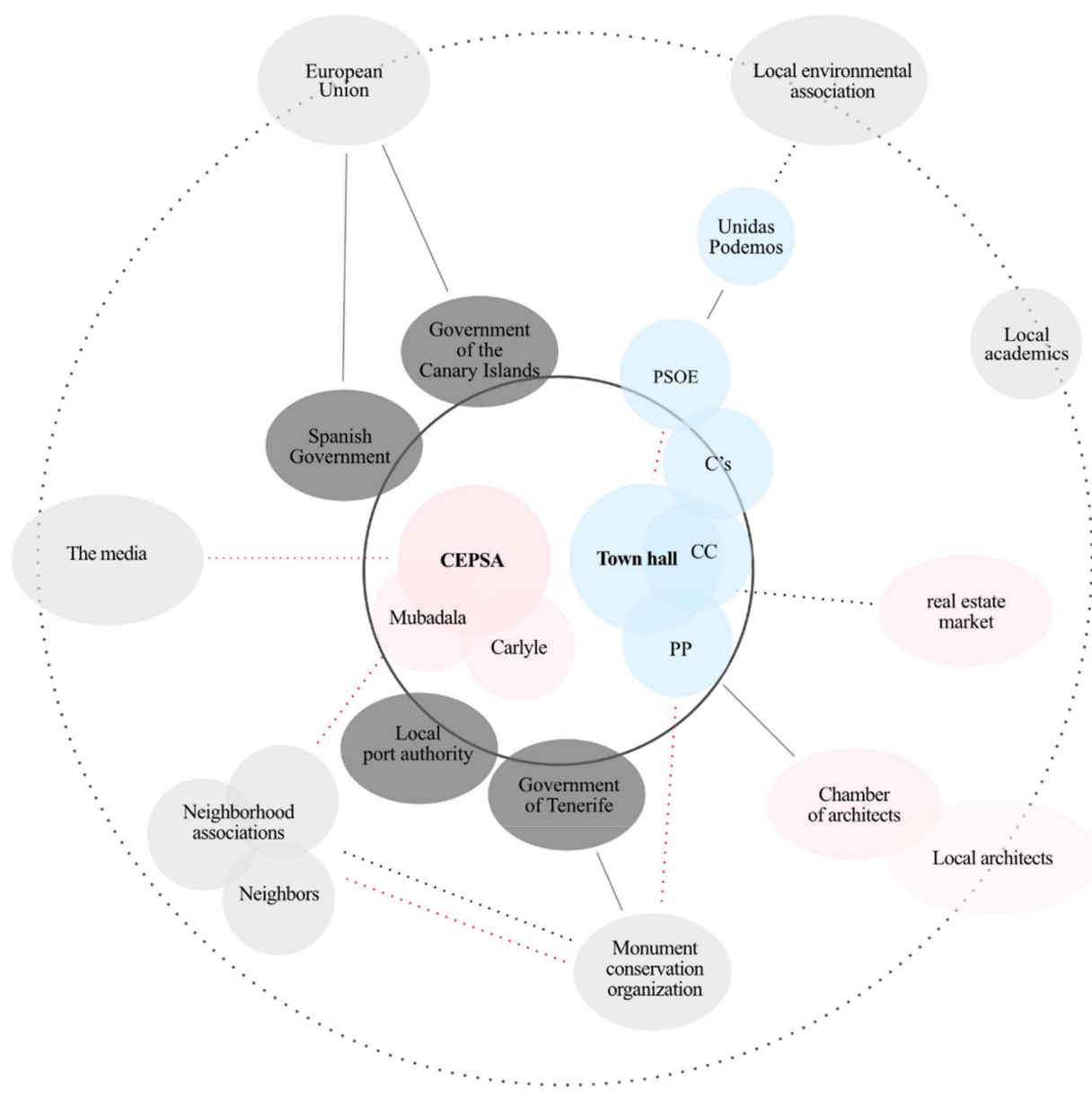

Local parties

Administrative institutions

Private entities

Other

Indirect relationship

Direct relationship

Conflictive relationship

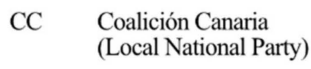

PP Partido Popular (Conservatives)

PSOE Partido Socialista Obrero Español (Socialists)

C's Ciudadanos

(Liberal Party)

Figure 5. Primary and secondary stakeholders within the network. Own elaboration based on the interviews.

The other primary stakeholder is the town hall of Santa Cruz. The two governing parties Coalición Canaria (CC, nationalist party) and Partido Popular (PP, conservatives) initiated the megaproject with CEPSA, and confirmed close coordination with the company (I6: 48, PP). As for Santa Cruz Verde 2030, there are two politicians who are particularly responsible: the mayor (CC, I13) and the chief officer in the Urban Development Office (PP, I6). The views of both were polarized among the secondary stakeholders. The politician of Partido Popular is regarded to "have a neoliberal concept" (I14: 49, Neighborhood association), while others confirmed that communicating and working with him was very easy (I10: 394, Chamber of Architects; I16: 74, Owner association). Several interviewees saw the motivations of the city government as linked to real estate interests (I15: 51, Unidas Podemos; I14: 84, Neighborhood association).

The PSOE (labor party) is a third important player. This party was in opposition when the megaproject was launched in summer 2018. After the municipal elections of May 2019, they gained mayoralty and hence became a primary stakeholder for approximately one year. Regarding their role within the megaproject, different narratives exist. Most interviewees stated that they had "other priorities" in the city (I10: 58, Chamber of Architects). "When I met the representatives of CEPSA again to see how the project was going, they made me understand that they lost one year" (I13: 52, Mayor). Contrary to that, others confirmed that they had had reunions with CEPSA (I11: 80, PSOE; I18: 64, CEPSA). Many stakeholders 
showed an understanding of the difficult situation of this new government, which also had to manage the COVID-19 pandemic (I18: 58, CEPSA).

A fourth group that has to be considered partly as a primary stakeholder is Ciudadanos (C's). Despite being a small party with only 2 out of 27 councilors in the city parliament [108], it was the political "kingmaker" in the government. In 2019, it helped to form a new socialist-liberal government with PSOE, and left CC and PP in the opposition. As for Santa Cruz Verde 2030, they stand out for two reasons. Firstly, one of their councilors was responsible for the Urban Development Office, but was very unsure about his role in the process: "I do not know the details of this plan" (I2: 6, C's), and "I prefer not to give my opinion, because you have to be careful and avoid a faux pas" (I2: 50, C's). Secondly, he left the government in summer 2020 due to internal conflicts (I15: 159, Unidas Podemos). The councilor who replaced him in the parliament made a new pact with PP and CC, and thus brought down the PSOE government.

Apart from the primary stakeholder named above, there are a couple of organizations, both public and private, that play a relevant role in the megaproject. Table 3 summarizes public organizations, while Table 4 presents those groups that have a certain influence on the process. Table 5 lists stakeholders that are relevant, but currently have a less prominent function.

Table 3. Governmental organizations.

\section{European Union}

- Has strengthened the environmental legislation in Spain, which has helped to regulate and control the oil refinery's activity on Tenerife (I15: 22, Unidas Podemos)

\section{Spanish Government}

- Is responsible for reviewing the demolition of the refinery (I13: 22, Mayor)

\section{Government of the Canary Islands}

- $\quad$ Governed by Coalición Canaria, it imposed the new Plan of Air Quality for Santa Cruz in 2014 (I13: 46, Mayor) and thus stopped CEPSA from refining

\section{Government of Tenerife}

- There is an ongoing discussion about whether it is the city government or the government of Tenerife that is responsible for Santa Cruz Verde 2030 (I10: 32, Chamber of Architects; I8: 40, Geographer)

- Is responsible for deciding if some of the refinery's buildings should be declared as "industrial heritage" (I4: 74, Preservationist)

\section{Local Port Authority}

- Has to find a new place for some of CEPSA's infrastructure in the harbor (I6: 102, PP)

- Is affected by the megaproject because one part of the coast belongs to them (I13: 22, Mayor; I18: 50, CEPSA)

\subsection{The Oil Refinery: Moving or Being Moved?}

Until now, there has not been much transparency about the deindustrialization process. Santa Cruz' mayor discussed it as follows: "I do not want to talk about that, I prefer to talk about the contract [ ... ]. Not about how we got here". However, I argue that it is specifically this "how" that is relevant to explore as regards who is currently shaping the city.

Figure 6 shows the location of the oil refinery and the different stages of industrial growth and shrinkage. In the 1990s, the refinery abandoned one third of its area (the eastern part), which was later transformed into the Cabo-Llanos neighborhood. This was a process in which local neighborhoods were displaced, and which was discussed as gentrification [20]. In the following, I will concentrate on why it was decided for the remaining area of the refinery to be dismantled (Santa Cruz Verde 2030). I will argue that there is a complex overlapping of reasons, and there are three categories of pressures that have led to the refinery's decision to withdraw, namely, environmental, urban, and entrepreneurial. 
Table 4. Further relevant stakeholders.

\section{Monument Preservation Association}

- Tried actively to form part of the process. They sent an application to the Government of Tenerife to protect some of the buildings of the refinery (I4: 74, Preservationist)

- Have already saved one of the refinery's tanks (El Tanque) in Cabo-Llanos and they keep defending it against neighborhood pressure (I16: 41, Owner association) and against the politician from PP who is trying to shut it down [109]

Chamber of Architects of Tenerife, La Gomera and El Hierro

- Is named by several stakeholders (I8, Geographer; I15, Unidas Podemos) as a necessary stakeholder with high prestige and knowledge (I6: 76, PP)

- Was asked by the town hall to organize the public event "+ciudad" and deliberate about the future of the megaproject with other experts (I10: 78, Chamber of Architects)

\section{The Media}

- $\quad$ Play different roles in this process

- $\quad$ Perform investigative journalism, as one interviewee (19, Journalist) tried to reveal the impact of the refinery on health issues

- Did not dare to report critically on the refinery in the past: "it is true that for many years, the contamination due to the refinery was censored" (I09: 101, Journalist)

- $\quad$ At the same time, they inform the public about the megaproject (I15: 88, Unidas Podemos; I14: 44, Neighborhoods association)

Real Estate Experts

- $\quad$ The megaproject might contribute to relaxing the tense housing market (I3: 38, Real estate agent), but at the same time, speculation is expected (I3: 42, Real estate agent)

- Want to accelerate the process of the megaproject (I1: 6, Real estate association)

Table 5. Peripheral stakeholders.

\section{Neighbors and Neighborhood Organizations}

- $\quad$ Have not played an active role so far (I16: 67, Owner association)

- $\quad$ They feared the refinery: "there was a certain fear that something would happen. Imagine, this was a bomb, tanks full of oil-it could explode at any moment" (I14: 177, Neighborhood association)

- $\quad$ Prefer to solve the problems in their own neighborhood first before investing in a new megaproject (I16: 10, Owner association)

\section{Local Environmental Association}

- Has not been very present in the public discussion, and they have not talked about the plan of the government in their association (I5: 72, Environmental association)

\section{Free Architects/Other Experts}

- $\quad$ Are neglected by the primary stakeholders, at least during this first phase of the project (I7: 211, former president of the Chamber of Architects; I8: 74, Geographer)

\section{Local University}

- The two scientists interviewed want their institutions to contribute (I8: 40, Geographer; I17: 170, Art historian)

- Are only named by one other interviewee as relevant (I15: 110, Unidas Podemos)

\section{Unidas Podemos (Left-Wing Party)}

- Supported the government of PSOE and C's from 06/2019 to 07/2020

- Compared to the other parties, they are furthest away from making decisions concerning Santa Cruz Verde 2030 (I15: 162, Unidas Podemos)

- Had an internal conflict concerning the refinery, and are near to the labor union, but also have a focus on environmental protection (I15: 12, Unidas Podemos)

There are obvious environmental factors for the increased pressure against the oil refinery, such as the pollution of the sea, soil, and air. As for the interviewees, the latter argument was the strongest (I15: 6, Unidas Podemos; I9: 91, Journalist; I11: 14, PSOE): "sometimes the whole quarter of Buenos Aires had to be evacuated" (I12: 18, Neighbor). However, this did not begin until 2013, when a report came out "that proved that the refinery increased mortality" (I9: 47, Journalist). Consequently, the regional government of the Canary Islands imposed a new Air Quality Plan for Santa Cruz, which stopped the industrial plant from refining in June 2014 (I13: 48, Mayor) because it demanded higher standards of emission protection. This government was led by the same party that would later come up with Santa Cruz Verde 2030 (Coalición Canaria). 


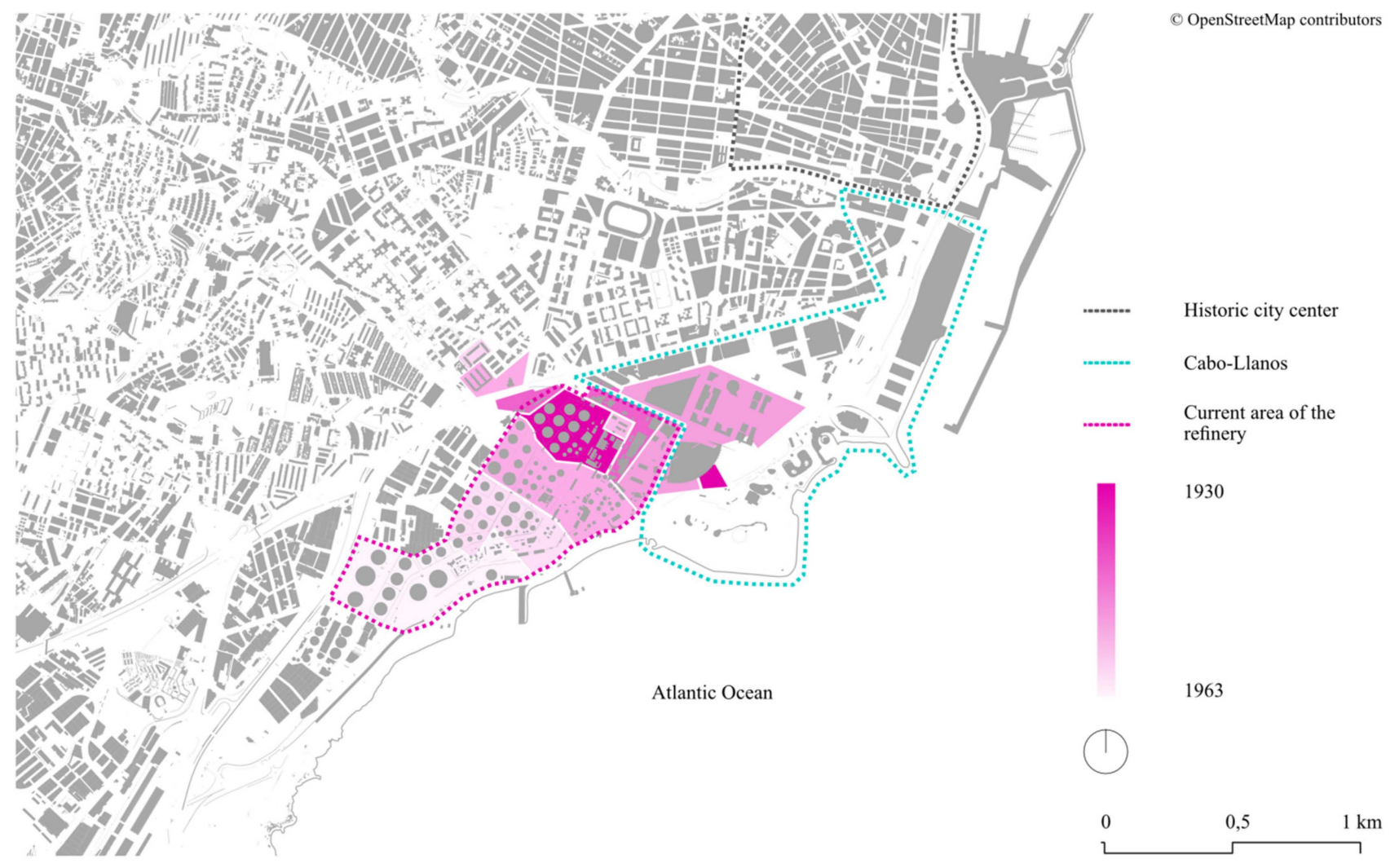

Figure 6. Expanding and dismantling the oil refinery on Tenerife. Own elaboration based on Open Street Map and Geofabrik GmbH [33] and Arencibia de Torres [110].

Secondly, several entrepreneurial factors led to the decision to dismantle the refinery. For the politician of the left-wing party, this was the major argument: "if the refinery was still profitable, it would still be refining" (I15: 16, Unidas Podemos). Contrary to that, CEPSA itself confirmed that "it was the new Air Quality Plan of Santa Cruz, that forced us to stop" (I18: 8, CEPSA). The underlying entrepreneurial argument here is that investing in the modernization of the industry did not seem profitable enough (I15: 20, Unidas Podemos). Apart from that, there are also interviewees who linked the shutdown of the refinery to the general transition towards the post-fossil era: "I believe that the oil issue, i.e., the energy model, is changing" (I10: 44, Chamber of Architects). Indeed, the oil refinery had stopped working already in 2013 because of problems on the oil market (I18: 8, CEPSA).

Apart from that, several interviewees suggested that the new owners of the refinery are more interested in investments in the field of real estate (I7: 85, Former president of Chamber of Architects; I1: 6, Real estate association; I9: 16, Geographer): "the Arabian sheiks know that constructing cities is a huge business" (I9: 45, Journalist). Applying the logic of a global company located in the Middle East, it does not make sense to run an oil refinery on Tenerife (I15: 20, Unidas Podemos). Interestingly, there were diverging narratives within the interviews. While CEPSA insisted on saying that it was a "mutual rapprochement" (I18: 39) between public governments and the company, the mayor emphasized that "the company came to us and I was quite surprised" (I13: 22).

The third type of pressure against the refinery is linked to urbanistic interests. The refinery "is the last area of expansion that Santa Cruz might have" (I11: 14, PSOE), as there is a severe shortage of space in the city (I1: 6, Real estate association; I10: 444, Chamber of Architects). Apart from that, the inner-city location of the industrial site also provokes problems: "a boulevard with containers on one side and apartments on the other side-that's not normal" (I13: 42, Mayor). CEPSA is aware of this pressure, but it sees itself rather as a victim here: "it was the city that moved closer to our infrastructure" (I18: 11). 
The urbanistic interest in developing the refinery's area can be explained with two parallel tendencies in the economic setting. On the one hand, stakeholders observed a decrease in economic weight of the refinery in Santa Cruz. The refinery was not only the "economic lung and supported by every party" (I11: 12, PSOE), but "there were even whole neighborhoods built just for the employees of the refinery" (I13: 44, Mayor) (see Figure 7). However, as the number of employees decreased year by year, CEPSA lost influence as well as representation in labor unions, who had influenced left-wing parties for many years (I8: 18, Geographer). On the other hand, there are strong interests in real estate and tourism: "I cannot prove it but it is obvious that there are plenty of entrepreneurs and building promoters who are interested in urbanizing this plot of land" (I09: 45, Journalist). The associate of the environmental association confirmed this: "Already before the refinery was closed, we heard a lot of voices in favor of closing the refinery which are not known for defending the quality of the environment, such as tourism developers, property developers etc." (I5: 52). Here, a linkage to the city's strategy to touristify the harbor area is seen (I8: 51, Geographer; I9: 68, Environmental association). This is a larger process, which has affected many other industrially used areas of the port in Santa Cruz [111] (p. 917). Accordingly, it is not surprising that "Coalición Canaria opened the fight against the refinery" (I9: 101, Journalist), as this party is regarded as representing real estate interests (I15: 51, Unidas Podemos; I14: 84, Neighborhood association).
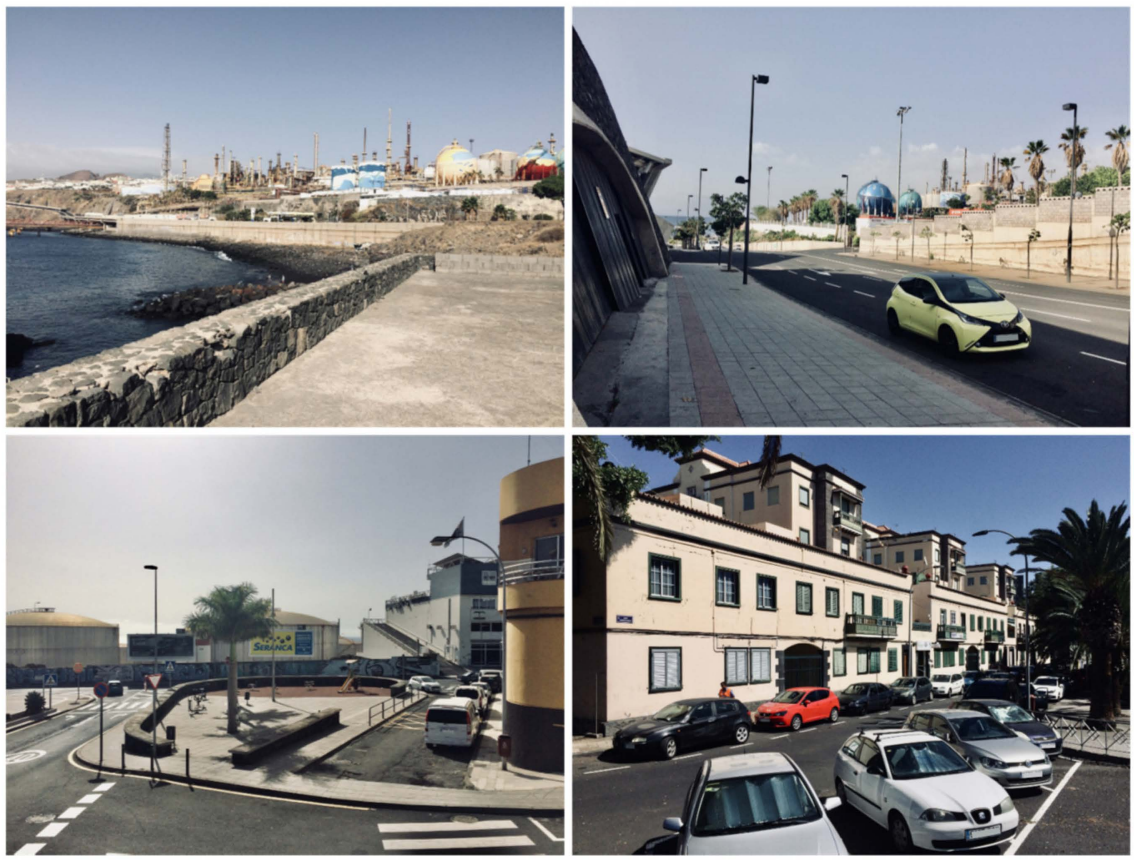

Figure 7. Top left: The refinery "Tenerife" seen from the Port of Honduras. Top right: The Center for Trade Fairs designed by Calatrava (left) and the walled oil refinery (right). Bottom left: Playground in the Buenos Aires neighborhood with the oil refinery in the background. Bottom right: Housing provided by CEPSA. Photos: the author.

\subsection{The Role of Tourism}

This section will shed light on the concept of Santa Cruz Verde 2030, and the perception of it. The announced plan contains a mix of uses (41\% green spaces, $21 \%$ housing, $10 \%$ public infrastructure) [21]. Functions such as housing and green spaces are not questioned by the stakeholders, and are even regarded as positive. The interviewees rather discussed unsolved aspects, such as the financing of the green spaces (I10: 297, Chamber of Architects), the quality of these spaces (I15: 128, Unidas Podemos; I4: 22, Preservationist), and the fear of real estate speculation (I3: 42, Real estate agent; I12: 75, Neighbor). Apart from this, I argue that it is tourism in particular (10\% urban hotels) that sticks out, for two reasons. 
Firstly, other studies have estimated that Santa Cruz Verde 2030 almost doubles the number of hotel beds in the city [23]. Secondly, the interviewees' opinions diverge more strongly in this field. Hence, I will put emphasis on this part of the concept.

As for the primary stakeholders, CEPSA has confirmed that it was the town hall itself that wanted to include urban hotels in Santa Cruz Verde 2030 (I18: 21, CEPSA). The PP's politician and chief officer in the Urban Development Office of the town hall argued that Santa Cruz is becoming a hub of cruise tourism, and there is a need for hotels where tourists can stay before or after their journey: "I insist, this idea of enlarging the touristic offer comes from there" (I6: 30).

As for the secondary stakeholders, different opinions about the role of tourism in Santa Cruz Verde 2030 exist. Some of the interviewees support the touristification strategy, for example, the Real estate association (I1: 59) and the political opposition (I11: 30, PSOE). It is stated that several studies show that Santa Cruz has a shortage of tourism supply (I10: 127, Chamber of Architects). The neighbor's argument supporting the idea of more tourism is linked to job creation: "in the end, Tenerife lives from tourism and Santa Cruz, too [ ... ] you have to think about the jobs" (I12: 89).

Others voiced doubts about the scope of the planned touristic development: "the question is not to build a hotel there, the question is, how. Just like the horrible new hotels in the south [of Tenerife]?" (I4: 120, Preservationist). Some of the interviewees were completely against the idea of more tourism (I8: 52, Geographer; I15: 39, Unidas Podemos). "Barcelona is a victim of tourism, I would not like it if Santa Cruz became a victim of tourism, too" (I17: 77, Art historian).

Contrary to that, the mayor denied that this is the goal of Santa Cruz Verde 2030: "the project plans with very few hotel beds, if you compare it to the south or the north [of Tenerife], the north has 30,000 beds. With Santa Cruz Verde 2030 we would go up to 3000 or 3500 in Santa Cruz" (I13: 18, Mayor). Although this argument seems logical, one has to question whether this is the appropriate scale of comparison, with the north of Tenerife being a partially touristified area and Santa Cruz a nontouristic [24] converted city [20]. Some interviewees observed a general tendency towards touristifying the city (I8: 52, Geographer; 19: 93, journalist) extending beyond the built infrastructure: "This is a government that stimulates short-term rentals" (I15: 39, Unidas Podemos).

In summary, the announced touristic function of Santa Cruz Verde 2030 has not given rise to consistent protests among secondary stakeholders, and there are several reasons for this:

- Compared to less controversial uses such as housing and green spaces, tourism accounts for a relatively small share- "these $10 \%$ [of tourism] do no frighten me" (I1: 59, Real estate association) —although it still accounts for 57,300 square meters. Additionally, for several interviewees, the other functions (housing and green spaces) were more relevant;

- Tourism infrastructure in the megaproject is linked to the demands of the inhabitants. One example is the planned construction of a beach, a project with high prestige that many inhabitants wish to pursue: "Santa Cruz has lost a beach a long time ago [ ... ]. Santa Cruz to the sea, I like that" (I12: 81, Neighbor);

- The economic dependency of the island on tourism is obvious, and tourism is linked to economic growth. This is seen as a major reason for why there is no critical discussion about tourism in Santa Cruz (I5: 68, Environmental association).

\subsection{Impacts}

The gap between primary and secondary stakeholders can also be seen in the discussion about the potential impacts of the megaproject. While the project description exclusively refers to positive effects [21], the reality will be more complex, and this sections offers insights into how the stakeholders evaluate the impacts.

First and foremost, discussing the impacts of the megaproject with the interviewees revealed it to be a question of spatial scale. When talking about the urban transformation, primary stakeholders preferred to refer to the whole city, as the project is seen as "an oppor- 
tunity to complete the urban development of Santa Cruz" (I13: 8, Mayor). This included, for example, the relation between Santa Cruz and the sea (I6: 76, PP). Primary stakeholders also referred to expanding the city towards the south (I13: 8, Mayor), increasing the urban touristic opportunities notably (I13: 18, Mayor) and solving the access problems that the city suffers from with regard to infrastructure (I2: 18, C's; I6: 10, PP).

In contrast, secondary stakeholders preferred to refer to the neighborhood scale, and also showed a more reflective understanding. On the positive side, interviewees named different aspects, such as less contamination (I15: 6, Unidas Podemos), as well as new infrastructure (I3: 46, Real estate agent) and the integration of currently segregated neighborhoods into the city (I1: 54, Real estate association). On the negative side, the interviewees named touristification (I8: 60, Geographer), but they were also cautious of a "bestial urbanism" (I5: 112, Environmental association), and that other parts of the city will be neglected (I16: 25, Owner association).

The example of gentrification as one consequence of the megaproject further exemplifies this controversial debate. For primary stakeholders and those representing real estate interests, there are some positive aspects of this. The value of neighboring quarters is expected to rise (I6: 80, PP), but this is seen as an advantage due to the high share of homeowners in Spain [112]. The mayor (I13: 40) added: "For these neighborhoods it is a great opportunity, in terms of public space but also revaluation of the existing houses". The former president of the Chamber of Architects (I7: 79) argued from an urbanistic point of view: "it is absurd to have four dilapidated houses there". It was even offered to form "an agreement with the neighbors and replace [the old houses] by new buildings with more height" (I1: 38, Real estate association). However, there were also differences between the primary stakeholders. While the PP politician regarded it as his responsibility to reduce negative impacts due to gentrification, the politician from Ciudadanos Party pointed out that "this is a free market of goods and values, we [the city government] do not have authorities here" (I2: 22, C's).

Contrary to that, there are also stakeholders who regarded gentrification as a major threat. Some interviewees came to this conclusion within the interview, but had not thought about it before (I5: 120, Environmental association). Others named gentrification explicitly when I asked about negative impacts in general (I8: 60, Geographer; I17: 128, Art historian). Neighbors were particularly critical and suspected that the megaproject will be "a neighborhood for the rich, with an impressive quality of life" (I14: 88, Neighborhood association). One neighbor put it this way: "we don't know if they will integrate or displace us" (I12: 39).

\subsection{Planning the Megaproject: From Hiding to Not Letting Participate}

The planning of this megaproject is doubtless a complex endeavor, as "there is no other example in Europe, where an oil refinery was transformed into a new city" (I13: 12, Mayor). In this section, I will summarize the stakeholders' opinions about this process of Santa Cruz Verde 2030, and identify gaps between primary and secondary stakeholders. The shortcomings lie in the areas of the public-private contract, participation, and transparency.

When I asked the interviewees their opinions about the plan, many of them primarily criticized the public-private contract and the fact that it was not very binding. Several stakeholders observed that the project puts a strong focus on image and marketing, rather than contents (I10: 415, Chamber of Architects; I15: 88, Unidas Podemos; I1: 24, Real estate association): "I thought it was like selling smoke" (I8: 38, Geographer). Apart from that, what has been presented in the contract [21] and in the media was seen critically. CEPSA and the town hall presented the project "because it looks good. When you read these statements, you will find all these trends of sustainable development. It's sustainable, it's self-sufficient, it's very green, there's a lot of public facilities, it all looks good" (I7: 30, former president of Chamber of Architects).

Additionally, the "real" terms of this contract are not clear at all (I10: 69, Chamber of Architects), but it is supposed that "the only realistic figure in this contract is the percentage that CEPSA is going to keep" (I4: 110, preservationist). The general concept also drew 
criticism (I16: 45, Owner association). With regard to the proposed share of each function [21] (p. 7), the preservationist noted that "Urbanism is not just percentages" (I4: 20). The former president of the Chamber of Architects could not see any overarching vision: "there are no strategic ideas, no ideas about what is the city, absolutely nothing" (I7: 26).

Participation was supposed to play a fundamental role "in all stages of the process" [21] (p. 6). In his interview, the mayor again confirmed the importance of this (I13: 24, Mayor). In contrast, all of the secondary stakeholders ensured that there was no true public discussion taking place on the megaproject: "there was only this one event organized by the Chamber of Architects during one afternoon, but that's all" (I7: 42, former president of the Chamber of Architects). The politicians in charge integrated neither the opinions of the refinery's neighborhoods (I16: 66, Owner association) nor those of the other relevant actors in the city, even years after initiating the project (I5: 82, Environmental association). Although in the future, there will be public participation by law, several interviewees suspect that it will be superficial (I14: 220, Neighborhood association; I7: 54, former president of Chamber of Architects), because "they [the primary stakeholders] have their own proposal and [ ... ] the people say what to add or what to take away, but the predefinition of that model normally excludes citizen participation" (I15: 51, Unidas Podemos). Confronted with these allegations, the mayor avoided a clear answer, and replied that "this is just one way of seeing it" (I13: 34, Mayor).

The lack of transparency has also contributed significantly to the negative associations of the stakeholders when it comes to the planning process (I10: 367, Chamber of Architects). None of the secondary stakeholders felt sufficiently informed about the project: "we do not know how the process was, why for example this percentage of green spaces?" (I15: 132, Unidas Podemos). In addition, the obscurity of the planning process is not trusted: "they [the town hall and CEPSA] would meet on a regular basis in order to work on the contract, almost in hidden way, so that no one would know" (I10: 430, Chamber of Architects).

However, all of the stakeholders underlined the importance of public discussion and participation: "they should give us a voice and consider our opinion. If they integrated the neighborhoods closest [to the refinery] such as ours, it would be better." (I12: 45, neighbor). Apart from the fact that participation enables fair access to shaping the city, much knowledge of what the city actually needs is held by the citizens (I10: 110, Chamber of Architects). The lack of transparency is a general problem in Spanish urbanism (I11: 34, PSOE), but due to European integration, Spain has been forced to make progress in this field (I5: 82, environmental association). Several stakeholder groups were named that should form part of this process, but the Chamber of Architects was named specifically as the most important group of experts (I8: 40, Geographer; I15: 26, Unidas Podemos; I6: $76, \mathrm{PP})$. However, apart from them, there are also plenty of other associations and interest groups that must not be forgotten (I17: 170, Art historian).

Restricting participation will have long-term impacts on the access of local stakeholders to this new neighborhood, but there have already been a couple of short-term consequences. For example, there was no political consensus about the megaproject (I15: 87, Unidas Podemos): "we got to know about the project five minutes before [the announcement] because the mayor called us" (I11: 34, PSOE). This had two project-relevant consequences. Firstly, the PSOE party, which was in the opposition at the time, immediately presented a court case against the public-private contract because according to their understanding it did not conform to the urbanistic law (I11: 24, PSOE) [113]. Secondly, one year after the announcement of Santa Cruz Verde 2030, PSOE and the C's took over the mayoralty after the municipal elections (see Figure 8). As there was no political consensus about the megaproject, the new parties in charge had their own visions about the project and the process, and decided to put other projects in the city first (I10: 58, Chamber of Architects). In sum, this political seesaw has confused many secondary stakeholders, and left them rather disappointed (I16: 43, Owner association; I12: 45, Neighbor). 


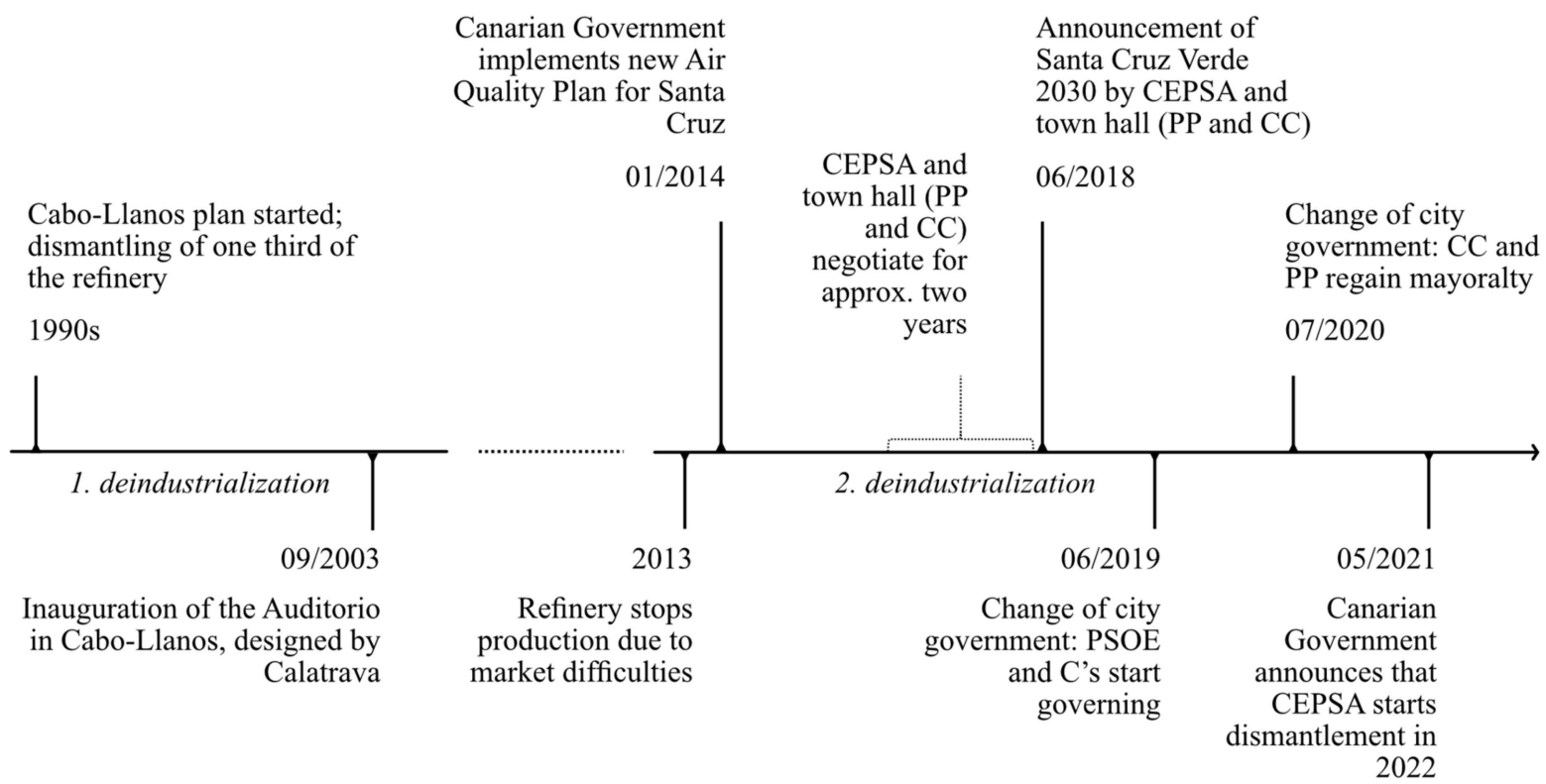

Figure 8. Two waves of deindustrialization dismantling Tenerife's oil refinery. Own elaboration based on Arencibia de Torres [110], Gobierno de Canarias [114], Ayuntamiento de Santa Cruz de Tenerife [21], Reverón [115], and the interviews.

\section{Discussion: The Right to Santa Cruz Verde 2030}

\subsection{A Megaproject-For Whom?}

Santa Cruz Verde 2030, regarded as "Spain's largest urbanistic operation" [17], will involve a fundamental transformation of urban space and further contribute to the observed touristification of the city's waterfront in a neoliberal setting [116]. From a critical perspective, converting the industrial land of the current oil refinery into a neighborhood with new functions such as housing and tourism raises two questions: It is not only "who" has the right to this conversion area, but also "how" this right should be facilitated. To explore this question, this paper makes use of the stakeholder approach to investigate local perceptions. I identify multiple gaps within these perceptions, with the major frontier lying between primary and secondary stakeholders. The most obvious disagreements are found in the field of planning and the potential impacts of the project, and the smallest relate to the project concept.

Santa Cruz Verde 2030 presents a mix of uses, with housing, tourism, and leisure being the "typical" pillars of many megaprojects around the globe [13] (p. 760). In terms of content, primary and secondary stakeholders are not far away from each other. However, I argue that the citizens' rights to the city are undermined, because the megaproject presents what is called top-down consent, produced "from above" [117] (p. 7). Although secondary stakeholders have not been asked, there is a degree of satisfaction with large parts of the megaproject concept. There are at least two reasons for this. Firstly, Santa Cruz Verde 2030 promises to tackle long-existing problems in the city's urban environment (a tense housing market, a lack of green spaces, traffic problems, and a lack of urban beach), and is thus presented as the panacea and "savior of the city" [52] (p. 81). Secondly, by offering a mix of several uses, different stakeholders have been satisfied [118] (p. 194), and are hence less likely to protest [14] (p. 787).

Within the megaproject, tourism accounts for only a small share (10\%), yet the project has considerable touristic potential. I consider this touristification through the back door, as the tourist functions are (a) masked behind a much larger portion of "desirable" green spaces, and (b) give rise to surprisingly little resistance among stakeholders, which can be partly traced back to the highly touristified setting on the Canary Islands. Consequently, discovering new urban spaces for tourism in Santa Cruz is less conflictive than the planning process itself - at least for a large share of the interviewees consulted. This is in line with 
the long-term production of a touristic image for the city, which was promoted by the local government during the last decades [116] (p. 430) and explains why local stakeholders might have gotten used to the prevailing tourism development. A transparent public debate about this issue must take place, given the multiple examples of touristification strategies in megaprojects having impacts on local inhabitants $[48,119,120]$.

Indeed, this paper shows how primary and secondary stakeholders use a different language, for example, when they refer to the spatial scales of the megaproject. For the stakeholders in charge, Santa Cruz Verde 2030 has first and foremost an importance for the whole city. This reflects the elites' desire to foster Santa Cruz's transformation into a more visible and more touristic city-which represents the paths that other cities are following [68] (p. 191). For secondary stakeholders, the relation to adjacent neighborhoods is more relevant. This is also shown in the intense discussion about gentrification, with regards to both the displacement of the refinery and future displacement pressure for different social groups.

The stakeholders discussed a variety of reasons for the deindustrialization of the refinery, but real estate and tourism play a major role here. However, the "visible" part of the battle over the refinery's area was fought in another arena, where environmental arguments were put first: "there is no doubt that this argument has come in handy" (I11: 14, PSOE). In addition, it is not only the groups putting environmental and urbanistic pressure on the refinery, but also the new international owners of CEPSA, who see a profitable deal in Santa Cruz Verde 2030. Hence, what I observe here is rather the "selfdisplacement" [121] (p. 1437) of an industry, revealing the global entrepreneurial logic of the elite [52] (p. 86); [117] (p. 7). The final dismantlement of Tenerife's refinery is hence one further step in the long-term deindustrialization process of Santa Cruz, and its attempt to turn towards a service-oriented economy [122].

Regenerating derelict industrial areas for service-oriented urban functions is a widespread phenomenon [123], and so is the active displacement of unwanted industrial functions [124]. Seeing this process through the lens of gentrification reveals a conceptual limitation here. The typical juxtaposition of "victim vs. aggressor" does not apply in this case study at first glance, as the owners of the land (CEPSA, Mubadala, Carlyle) actively initiated the urbanistic operation, and will profit from it. Additionally, as the project is taking place in an industrial area, no inhabitants are being displaced directly, and so this project will probably "not stimulate the resistance" of society [13] (p. 760).

However, I see at least three groups of people that will be displaced. Firstly, this applies to industrial workers, who will lose their jobs due to the refinery being closed down. In this sense, Curran has argued for the gentrification concept, and regards both "home and work" as "equally important aspects of community" [121] (p. 1438)-a proposal that this paper supports. Secondly, neighbors in adjacent quarters will experience the disadvantages of the upgrading in the long term if they leave their homes because of the socio-cultural changes that are to be expected, or because of economic pressure on the housing market [125]. Thirdly, exclusionary displacement in Marcuse's sense [126] (p. 206) will prevent lower-income households from moving into the new neighborhood of Santa Cruz Verde 2030, if the project fails to become integrative.

\subsection{A Megaproject-By Whom?}

Primary stakeholders in the megaproject Santa Cruz Verde 2030, both public and private, have revealed a clear and unanimous understanding of the new form of governance, "characterized by less democratic and more elite-driven priorities" [90] (p. 547). This is reflected in the fact that in the first four years since Santa Cruz Verde 2030 was announced, primary stakeholders have made all the decisions, without letting secondary stakeholders participate. Despite the multiple promises that participation will be enabled later, the main problem is that CEPSA and the townhall proposed a model with predefined elements (tourism, housing, beach, green spaces), without consulting the community. This is a common problem in large-scale urban projects [14,127] (p. 1400), and it puts primary 
stakeholders into a box, whereby the only assurance of the project's legitimacy is its success [128] (p. 15).

Communication has played an ambiguous role in this process, and different strategies have been implemented by CEPSA and the local governments led by CC and PSOE; however, both of the local parties are viewed very critically by secondary stakeholders.

Apart from the public announcement of the project, CEPSA does not put effort into marketing the megaproject (I5: 32, Environmental association), and they even avoid public discussion (I10: 396, Chamber of Architects). Consequently, negative perceptions of the megaproject are associated with the town hall.

Contrary to that, the initiators of the megaproject (CC, PP) have put too much emphasis on marketing and image, and thus follow the trend of constructing a competitive advantage in a neoliberal setting by means of megaprojects [129] (p. 4). Producing a "successful project" is hence a fundamental part of the marketing strategy [51] (p. 42), but it is particularly this neglect of contents that has made secondary stakeholders skeptical.

The interim government consisting of PSOE and C's that was in charge from 2019 to 2020 followed a different strategy, as it did not communicate its intentions regarding the project at all, and was thus viewed as "doing nothing" (I10: 60, Chamber of Architects).

This imbalance between contents and communication has confused local stakeholders significantly. Hence, the case of Santa Cruz Verde 2030 helps us further understand why, four decades after Spain's transition to democracy, "any discussion of their [large-scale urban projects'] content and design are practically nonexistent" in the country [68] (p. 192). In this sense, megaprojects contribute to the "erosion of democracy" [84] (p. 68), due to their technocratic character and focus on expert knowledge.

This study has investigated a local process of urban regeneration, as well as showcasing "competitive restructuring [ ... ] on a global scale" [130] (p. 9), revealing the overlapping local, national, and global interests of the elite [90] (p. 576). Santa Cruz Verde 2030 is expected to reconfigure the city's relation with the sea, and it will deliver a functional bridge with the water; the question, though, is will it also offer what Swyngedouw et al. called a "social bridge" [90] (p. 577)? Experience gained from other projects shows the opposite, given the polarizing impact of large-scale urban development projects $[66,131]$ and their exclusiveness [132] (p. 391). As for the case of Santa Cruz, I have offered two perspectives from which to approach the right to Santa Cruz Verde 2030 by referring to the project concept and the process from the stakeholders' perspective. The deficits that this paper describes should be understood as a wake-up call for local stakeholders, prompting them to question whether or not this is how best to build a city of the 21st century.

Funding: This research received no external funding. I acknowledge support from Leipzig University for Open Access Publishing.

Informed Consent Statement: All interviewees gave their informed consent for inclusion before they participated in the study.

Data Availability Statement: Not applicable.

Acknowledgments: I want to thank the reviewers and the local interviewees for their valuable time and for contributing to this study.

Conflicts of Interest: The author declares no conflict of interest.

\section{References}

1. Keul, A. Tourism Neoliberalism and the Swamp as Enterprise. Area 2014, 46, 235-241. [CrossRef]

2. Kagermeier, A.; Amzil, L.; Elfasskoui, B. Touristification of the Moroccan Oasis Landscape: New Dimensions, New Approaches, New Stakeholders and New Consumer Formulas. Chang. et Formes D'adaptation Dans Les Espaces Ruraux. 2019. Available online: http:/ / wordpress.kagermeier.de/wp-content/uploads/2018/08/Kagermeier-Amzil-Elfasskaoui_Colloque-Ait-Hamza_ Tourisme-Oasis-Maroc_26-09-2017.pdf (accessed on 10 January 2022).

3. Burgold, J.; Frenzel, F.; Rolfes, M. Observations on slums and their touristification. Die Erde 2013, 144, 99-104.

4. Blanco-Romero, A.; Blázquez-Salom, M.; Morell, M.; Fletcher, R. Not tourism-phobia but urban-philia: Understanding stakeholders' perceptions of urban touristification. Bol. Asoc. Geógr. Esp. 2019, 83, 1-30. [CrossRef] 
5. Sequera, J.; Nofre, J. Shaken, not stirred. New debates on touristification and the limits of gentrification. City 2018, 22, 843-855. [CrossRef]

6. Mendes, L. Tourism Gentrification in Lisbon. The Panacea of Touristification as a Scenario of Post-Capitalist Crisis. In Crisis, Austerity, and Transformation. How Disciplinary Neoliberalism is Changing Portugal; David, I., Ed.; Lexington Books: Lanham, MD, USA, 2018; pp. 25-47.

7. Del Romero Renau, L. Touristification, Sharing Economies and the New Geography of Urban Conflicts. Urban Sci. 2018, 2, 104. [CrossRef]

8. UNWTO. World Tourism Organization. International Tourism Highlights; UNWTO: Madrid, Spain, 2019. Available online: https: //www.e-unwto.org/doi/book/10.18111/9789284421152 (accessed on 11 January 2022).

9. Statista. Evolución Anual del Número de Visitantes Internacionales en España de 2006 a 2020, Por Tipo. Available online: https:/ / es.statista.com/estadisticas/474658/visitantes-extranjeros-en-espana-por-tipo/ (accessed on 11 January 2022).

10. Bugalski, $€$. The Undisrupted Growth of the Airbnb Phenomenon between 2014-2020. The Touristification of European Cities before the COVID-19 Outbreak. Sustainability 2020, 12, 9841. [CrossRef]

11. Fainstein, S. Mega-projects in New York, London and Amsterdam. Int. J. Urban Reg. Res. 2009, 768-785. [CrossRef]

12. Majoor, S. Framing Large-Scale Projects: Barcelona Forum and the Challenge of Balancing Local and Global Needs. J. Plan. Educ. Res. 2011, 31, 143-156. [CrossRef]

13. Diaz Orueta, F.; Fainstein, S. The New Mega-Projects: Genesis and Impacts. Int. J. Urban Reg. Res. 2009, 32, 759-767. [CrossRef]

14. Lehrer, U.; Laidley, J. Old Mega-Projects Newly Packaged? Waterfront Redevelopment in Toronto. Int. J. Urban Reg. Res. 2008, 32, 786-803. [CrossRef]

15. Jordhus-Lier, D. Community resistance to megaprojects: The case of the N2 Gateway project in Joe Slovo informal settlement, Cape Town. Habitat Int. 2015, 45, 169-176. [CrossRef]

16. Di Maddaloni, F.; Davis, K. The influence of local community stakeholders in megaprojects: Rethinking their inclusiveness to improve project performance. Int. J. Proj. Manag. 2017, 35, 1537-1556. [CrossRef]

17. Millet, D. El Gobierno Local Allana el Camino a la «Mayor Operación Urbanística del País». El Día. 2022. Available online: https:/ / www.eldia.es/santa-cruz-de-tenerife/2022/01/31/gobierno-local-allana-camino-mayor-62129684.html?pimecsource $=$ www.eldia.es\&pimec-widget=1\&pimec-config=2\&pimec-mod=0\&pimec-pos=2 (accessed on 10 February 2022 ).

18. ISTAC Instituto Canario de Estadística. Población. Municipios por Islas de Canarias y Años. Available online: http://www. gobiernodecanarias.org/istac/jaxi-istac/tabla.do (accessed on 2 February 2022).

19. González Chávez, C.M. Nuevas propuestas arquitectónicas y de equipamiento urbano en el siglo XXI. El futuro de Cabo-Llanos en Santa Cruz de Tenerife (Canarias). Arte Y Ciudad. Rev. De Investig. 2018, 14, 33-64.

20. García Herrera, L.M.; Smith, N.; Mejías Vera, M.Á. Gentrification, Displacement, and Tourism in Santa Cruz de Tenerife. Urban Geogr. 2007, 28, 276-298. [CrossRef]

21. Ayuntamiento de Santa Cruz de Tenerife; CEPSA. Acuerdo de Colaboración Público-Privada para el Plan Santa Cruz Verde 2030. Available online: https://www.santacruzdetenerife.es/scverde2030/fileadmin/user_upload/web/SCverde2030/NotadePrensa2 6062018.pdf (accessed on 10 January 2019).

22. Gonar, H. 'Santa Cruz 2030' Supondrá un Ahorro en el Proyecto del Tren del Sur. El Día 2022. Available online: https: //www.eldia.es/santa-cruz-de-tenerife/2022/02/09/santa-cruz-2030-supondra-ahorro-62474037.html (accessed on 2 March 2022).

23. Hübscher, M. From megaprojects to tourism gentrification? The case of Santa Cruz Verde 2030 (Canary Islands, Spain). Bol. Asoc. Geógr. Esp. 2019, 83, 1-47. [CrossRef]

24. Hübscher, M.; Schulze, J.; Zur Lage, F.; Ringel, J. The Impact of Airbnb on a Non-Touristic City. A Case Study of Short-Term Rentals in Santa Cruz de Tenerife (Spain). Erdkunde 2020, 74, 191-204. [CrossRef]

25. INE-Instituto Nacional de Estadística. Número de Turistas Según Comunidad Autónoma de Destino Principal. Available online: https:/ / www.ine.es/jaxiT3/Datos.htm?t=10823 (accessed on 11 January 2022).

26. Cheer, J.; Cole, S.; Reeves, K.; Kato, K. Tourism and Islandscapes: Cultural realignment, social-ecological resilience and change. Shima 2017, 11, 40-54. [CrossRef]

27. Baixinho, A.; Santos, C.; Couto, G.; de Albergaria, I.S.; da Silva, L.S.; Medeiros, P.D.; Simas, R.M.N. Islandscapes and Sustainable Creative Tourism: A Conceptual Framework and Guidelines for Best Practices. Land 2021, 10, 1302. [CrossRef]

28. Armas-Díaz, A.; SaBaté-Bel, F.; Murray, I.; Blázquez-Salom, M. Beyond the Right to the Island: Exploring Protests against the Neoliberalization of Nature in Tenerfie (Canary Islands, Spain). Erdkunde 2020, 74, 249-262. [CrossRef]

29. Hof, D. Home Dispossession and Commercial Real Estate Dispossession in Tourist Conurbations. Analyzing the Reconfiguration of Displacement Dynamics in Los Cristianos/Las Américas (Tenerife). Urban Sci. 2021, 5, 30. [CrossRef]

30. Nimführ, S.; Otto, L. Doing research on, with and about the island: Reflections on islandscape. Isl. Stud. J. 2020, 15, 185-204. [CrossRef]

31. Cabildo de Tenerife. Cifras Padronales. Available online: https://www.tenerifedata.com/dataset/cifras-padronales (accessed on 11. January 2022).

32. Turismo de Tenerife. Indicadores Turísticos de Tenerife. 2022. Available online: https://www.webtenerife.com/investigacion/ situacion-turistica / indicadores-turisticos / ?filter-year=2019 (accessed on 11 January 2022). 
33. Open Street Map; Geofabrik GmbH. OpenStreetMap Data Extracts. Available online: https://download.geofabrik.de (accessed on 11 January 2022).

34. Füller, H.; Michel, B. 'Stop Being a Tourist!' New Dynamics of Urban Tourism in Berlin-Kreuzberg. Int. J. Urban Reg. Res. 2014, 38, 1304-1318. [CrossRef]

35. Harvey, D. From Managerialism to Entrepreneurialism: The Transformation in Urban Governance in Late Capitalism. Geogr. Annaler. Ser. B Hum. Geogr. 1989, 71, 3-17. [CrossRef]

36. Fainstein, S.; Judd, D. Cities as Places to Play. In The Tourist City; Judd, D.F., Susan, S.F., Eds.; Yale University Press: New Haven, CT, USA; London, UK, 1999; pp. 261-272.

37. Cohen, E. Authenticity and Commoditization in Tourism. Ann. Tour. Res. 1988, 15, 371-386. [CrossRef]

38. Aytar, V.; Rath, J. Selling Ethnic Neighborhoods. The Rise of Neighborhoods as Places of Leisure and Consumption; Routledge: New York, NY, USA, 2012.

39. Dirksmeier, P.; Helbrecht, I. Resident Perceptions of New Urban Tourism: A Neglected Geography of Prejudice. Geogr. Compass 2015, 9, 276-285. [CrossRef]

40. Voase, R. Creating the Tourist Destination: Narrating the Undiscovered and the Paradox of Consumption. In Tourism, Consumption and Representation: Narratives of Place and Self; Meethan, K., Anderson, A., Miles, S., Eds.; CABI: Kings Lynn, UK, 2006; pp. 284-300.

41. Sequera, J.; Nofre, J. Touristification, transnational gentrification and urban change in Lisbon: The neighbourhood of Alfama. Urban Stud. 2019, 57, 3169-3189. [CrossRef]

42. Ojeda, A.; Kieffer, M. Touristification. Empty concept or element of analysis in tourism geography? Geoforum 2020, 115, 143-145 [CrossRef]

43. Gotham, K.F. Tourism Gentrification: The Case of New Orleans' Vieux Carre (French Quarter). Urban Stud. 2005, 42, 1099-1121 [CrossRef]

44. Wachsmuth, D.; Weisler, A. Airbnb and the Rent Gap: Gentrification Through the Sharing Economy. Environ. Plan. A Econ. Space 2018, 50, 1147-1170. [CrossRef]

45. Enright, T. The political topology of urban uprisings. Urban Geogr. 2017, 38, 557-577. [CrossRef]

46. Doucet, B.; Van Kempen, R.; Van Weesep, J. Resident Perceptions of Flagship Waterfront Regeneration: The Case of the Kop Van Zuid in Rotterdam. Tijdschr. Voor Econ. En Soc. Geogr. 2010, 102, 125-145. [CrossRef]

47. Hübscher, M. Megaprojects, Gentrification, and Tourism. A Systematic Review on Intertwined Phenomena. Sustainability 2021, 13, 12827. [CrossRef]

48. Salom, J.; Pitarch, M.; Albertos, J. Desired and undesired effects of the tourism development policy based on megaprojects: The case of Valencia (Spain). Eur. J. Geogr. 2019, 10, 132-148.

49. Del Cerro Santamaría, G. The Alleged Bilbao Miracle and its Discontents. In Urban Megaprojects: A Worldwide View; Del Cerro Santamaría, G., Ed.; Emerald Group Publishing Limited: Bingley, UK, 2013; Volume 13, pp. 27-59.

50. Moulaert, F.; Swyngedouw, E.; Rodriguez, A. Large Scale Urban Development Projects and Local Governance: From Democratic Urban Planning to Besieged Local Governance. Geogr. Z. 2001, 89, 71-84.

51. Hufeisen, J. Der "Sprung über die Elbe"-Zivilgesellschaftliche Strategien der Teilhabe an Stadtentwicklungsprozessen auf den Hamburger Elbinseln. In Sozialraum und Governance. Handeln und Aushandeln in der Sozialraumentwicklung; Alisch, M., Ed.; Verlag Barbara Budrich: Opladen/Berlin, Germany; Toronto, ON, Canada, 2015.

52. Harris, M. Competitive Precinct Projects: The Five Consistent Criticisms of "Global" Mixed-Use Megaprojects. Proj. Manag. J. 2017, 48, 76-92. [CrossRef]

53. Adityanandana, M.; Gerber, J.-F. Post-growth in the Tropics? Contestations over Tri Hita Karana and a tourism megaproject in Bali. J. Sustain. Tour. 2019, 27, 1839-1856. [CrossRef]

54. Girma, M.; Singh, M. The Impact of Megaprojects on Branding Ethiopia as an Appealing Tourist Destination. J. Environ. Manag. Tour. 2018, 8, 1733-1744. [CrossRef]

55. Cocola-Gant, A. Tourism gentrification. In Handbook of Gentrification Studies; Lees, L., Phillips, M., Eds.; Edward Elgar Publishing: Cheltenham/Northampton, UK, 2018.

56. Colomb, C.; Novy, J. Protest and Resistance in the Tourist City; Routledge, Tayler \& Francis: London, UK, 2016.

57. Ardura Urquiaga, A.; Lorente-Riverola, I.; Ruiz Sanchez, J. Platform-mediated short-term rentals and gentrification in Madrid. Urban Stud. 2020, 57, 3095-3115. [CrossRef]

58. Gravari Barbas, M.; Guinand, S. Tourism and Gentrification in Contemporary Metropolises. International Perspectives; Routledge: London, UK; New York, NY, USA, 2017.

59. Diaz-Parra, I.; Jover, J. Overtourism, place alienation and the right to the city: Insights from the historic centre of Seville, Spain. J. Sustain. Tour. 2021, 29, 158-175. [CrossRef]

60. Torkington, K.; Perdigão Ribeiro, F. Whose right to the city? An analysis of the mediatized politics of place surrounding alojamento local issues in Lisbon and Porto. J. Sustain. Tour. 2020, 1-20. [CrossRef]

61. Plichta, J. The co-management and stakeholders theory as a useful approach to manage the problem of overtourism in historical cities-illustrated with an example of Krakow. Int. J. Tour. Cities 2019, 5, 685-699. [CrossRef]

62. World Tourism Organization (UNWTO); Centre of Expertise Leisure, Tourism \& Hospitality; NHTV Breda University of Applied Sciences; NHL Stenden University of Applied Sciences. 'Overtourism'?—Understanding and Managing Urban Tourism Growth 
beyond Perceptions, Executive Summary; Madrid, Spain, 2018. Available online: https://www.e-unwto.org/doi/book/10.18111 /9789284420070 (accessed on 2 March 2022).

63. Goodwin, H. The Challenge of Overtourism. Responsible Tour. Partnership. 2017. Available online: https://www.millenniumdestinations.com/uploads/4/1/9/7/41979675/rtpwp4overtourism012017.pdf (accessed on 10 January 2022).

64. Brookes, N. Mankind and Mega-projects. Front. Eng. Manag. 2014, 1, 241-245. [CrossRef]

65. Leick, A.; Hesse, M.; Becker, T. From the "project within the project" to the "city within the city"? Governance and Management Problems in Large Urban Development Projects Using the Example of the Science City Belval, Luxembourg. Spat. Res. Plan. 2020, 78, 1-17.

66. Gellert, P.; Lynch, B. Mega-projects as displacements. Int. Soc. Sci. J. 2003, 55, 15-25. [CrossRef]

67. Bruzelius, N.; Flyvbjerg, B.; Rothengatter, W. Big decisions, big risks. Improving accountability in mega projects. Transp. Policy 2002, 9, 143-154. [CrossRef]

68. Díaz Orueta, F. Madrid: Urban regeneration projects and social mobilization. Cities 2007, 24, 183-193. [CrossRef]

69. Flyvbjerg, B. The Oxford Handbook of Megaproject Management; Flyvbjerg, B., Ed.; CPI Group: London, UK, 2017.

70. Flyvbjerg, B.; Bruzelius, N.; Rothengatter, W. Megaprojects and Risk: An Anatomy of Ambition; Cambridge University Press: Cambridge, UK, 2003.

71. Del Cerro Santamaría, G. Urban Megaprojects: A Worldwide View; Emerald: Bingley, UK, 2013.

72. Flyvbjerg, B. Machiavellian megaprojects. Antipode 2005, 37, 18-22. [CrossRef]

73. UN Habitat. Sustainable Development Goals. Monitoring Human Settlements Indicators. 2015. Available online: https: / / unhabitat.org/sites/default/files/2020/06/sustainable_development_goals_summary_version.pdf (accessed on 12 January 2022).

74. BBSR-Federal Institute for Research on Building. The New Leipzig Charter. The Transformative Power of Cities for the Common Good. 2021. Available online: https://www.bmi.bund.de/SharedDocs/downloads/EN/eu-presidency/ gemeinsame-erklaerungen/new-leipzig-charta-2020.pdf;jsessionid=ADE8FB60A490BDA3AEAA0F3672A82E6F.1_cid364?_ _blob=publicationFile\&v=7 (accessed on 12 January 2022).

75. Gobierno de España. Urbana, M.d.T.M.y.A. AUE-Agenda Urbana Española 2019, Plan de Acción. 2019. Available online: https://www.aue.gob.es/recursos_aue/06_plan_de_accion_age.pdf (accessed on 12 January 2022).

76. Ajam, M. Leading Megaprojects. A Tailored Approach; Auerbach Publications: Boca Raton, FL, USA, 2020.

77. Drouin, N.; Sankaran, S.; Marrewijk, A.; Müller, R. 18. Conclusions and reflections: What have we learnt about megaproject leaders? In Megaproject Leaders. Reflections on Personal Life Stories; Drouin, N., Sankaran, S., Marrewijk, A., Müller, R., Eds.; Edward Elgar Publishing: Cheltenham, UK, 2021; pp. 288-297.

78. Di Maddaloni, F.; Davis, K. Project manager's perception of the local communities' stakeholder in megaprojects. An empirical investigation in the UK. Int. J. Proj. Manag. 2017, 36, 542-565. [CrossRef]

79. Delphine; Witte, P.; Spit, T. Megaprojects-An anatomy of perception: Local people's perceptions of megaprojects: The case of Suramadu, Indonesia. disP-Plan. Rev. 2019, 55, 63-77. [CrossRef]

80. Anzoise, V.; Slanzi, D.; Poli, I. Local stakeholders' narratives about large-scale urban development: The Zhejiang Hangzhou Future Sci-Tech City. Urban Stud. 2020, 57, 655-671. [CrossRef]

81. Gonzalez-Porras, L.; Heikkinen, A.; Kujala, J. Understanding stakeholder influence: Lessons from a controversial megaproject. Int. J. Resour. Dev. Manag. 2021, 21, 191-213.

82. Eskerod, P.; Huemann, M.; Savage, G. Project Stakeholder Management-Past and Present. Proj. Manag. J. 2015, 46, 6-14. [CrossRef]

83. Lane, M. Public Participation in Planning: An intellectual history. Aust. Geogr. 2005, 36, 283-299. [CrossRef]

84. Tarazona Vento, A. Mega-project meltdown: Post-politics, neoliberal urban regeneration and Valencia's fiscal crisis. Urban Stud. 2017, 54, 68-84. [CrossRef]

85. Ibert, O. Megaprojekte und Partizipation. Konflikte zwischen handlungsorientierter und diskursiver Rationalität in der Stadtentwicklungsplanung. disP-Plan. Rev. 2007, 171, 50-63. [CrossRef]

86. Shatkin, G. Planning Privatopolis: Representation and Contestation in the Development of Urban Integrated Mega-Projects. In Worlding Cities: Asian Experiments and the Art of Being Global; Roy, A., Ong, A., Eds.; Wiley-Blackwell: Chichester, UK, 2011; pp. 77-97.

87. Zeković, S.; Maričić, T.; Vujošević, M. Megaprojects as an instrument of urban planning and development: Example of Belgrade Waterfront. In Technologies for Development: From Innovation to Social Impact; Hostettler, S., Najih Besson, S., Bolay, J.-C., Eds.; Springer: Cham, Switzerland, 2018; pp. 153-164.

88. Soja, E. The city and spatial justice. In Proceedings of the Spatial Justice, Nanterre, Paris, France, 12-14 March 2009; pp. 1-5.

89. Marcuse, P. Spatial justice: Derivative but Causal of Social Justice. In Justice et Injustices Spatiales; Bret, B., Gervais-Lambony, P., Hancock, C., Landy, F., Eds.; Presses Universitaires de Paris Nanterre: Nanterre, France, 2010; pp. 76-92.

90. Swyngedouw, E.; Moulaert, F.; Rodriguez, A. Neoliberal Urbanization in Europe: Large-Scale Urban Development Projects and the New Urban Policy. Antipode 2002, 34, 542-577. [CrossRef]

91. Ferber, U.; Grimski, D.; Millar, K.; Nathanail, P. Sustainable Brownfield Regeneration; University of Nottingham: Nottingham, 2006. Available online: https:/ / issuu.com/guspin/docs/nameaa6734 (accessed on 20 November 2020). 
92. Ortiz, A. The Qualitative Interview. In Research in the College Context, 2nd ed.; Stage, F., Manning, K., Eds.; Routledge: London, UK, 2015; pp. 57-71.

93. Taylor, C. Interviewing. In Qualitative Research in Health Care; Holloway, I., Ed.; McGraw-Hill: Maidenhead, UK, $2005 ;$ pp. 39-54.

94. Kallio, H.; Pietilä, A.-M.; Johnson, M.; Kangasniemi, M. Systematic methodological review: Developing a framework for a qualitative semi-structured interview guide. J. Adv. Nurs. 2016, 72, 2954-2965. [CrossRef]

95. Hernández Sempieri, R.; Fernández Collado, C.; Baptista Lucio, M.d.P. Metodología de la Investigación, 5th ed.; Mc Graw Hill: Mexico City, Mexico, 2010.

96. Dierckx de Casterle, B.; Gastmans, C.; Bryon, E.; Denier, Y. QUAGOL: A guide for qualitative data analysis. Int. J. Nurs. Stud. 2012, 49, 360-371. [CrossRef]

97. Kuckartz, U. Qualitative Inhaltsanalyse. Methoden, Praxis, Computerunterstützung, 4th ed.; Beltz Juventa: Weinheim, Germany, 2018.

98. Mayring, P. Qualitative Content Analysis. Theoretical Foundation, Basic Procedures and Software Solution; Beltz: Klagenfurt, Slovenia, 2014.

99. Queirós, A.; Faria, D.; Almeida, F. Strengths and Limitations of Qualitative and Quantitative Research Methods. Eur. J. Educ. Stud. 2017, 3, 369-387.

100. Alsaawi, A. A Critical Review of Qualitative Interviews. Eur. J. Bus. Soc. Sci. 2014, 3, 149-156. [CrossRef]

101. Peräkylä, A. Validity in Qualitative Research. In Qualitative Research, 3rd ed.; Silverman, D., Ed.; Sage: Thousand Oaks, CA, USA, 2011; pp. 413-427.

102. Silverman, D. Introducing Qualitative Research. In Qualitative Research, 3rd ed.; Silverman, D., Ed.; Sage: Thousand Oaks, CA, USA, 2011; pp. 3-14.

103. Genz, C.; Tschoepe, A.Y. Ethnographie als Methodologie. Zur Erforschung von Räumen und Raumpraktiken. In Handbuch Qualitative und Visuelle Methoden der Raumforschung; Heinrich, A.J., Marguin, S., Million, A., Stollmann, J., Eds.; Transcript: Bielefeld, Germany, 2021; pp. 225-236.

104. Crouch, M.; McKenzie, H. The logic of small samples in interview-based qualitative research. Soc. Sci. Inf. 2006, 45, 483-499. [CrossRef]

105. Rädiker, S.; Kuckartz, U. Focused Analysis of Qualitative Interviews with MAXQDA. Step by Step; MAXQDA Press: Berlin, Germany, 2020.

106. El País. El Fondo IPIC de Abu Dabi Compra el 100\% de Cepsa. El País. 2011. Available online: https://elpais.com/economia/20 11/02/16/actualidad/1297845181_850215.html (accessed on 14 January 2022).

107. Mubadala; The Carlyle Group. Media Release; 14.01.2022. 2019. Available online: https://www.cepsa.com/stfls/corporativo/ FICHEROS/NOTAS_DE_PRENSA/Mubadala-Carlyle-Press-Release.pdf (accessed on 14 January 2022).

108. El País. 26M Elecciones Municipales, Santa Cruz de Tenerife. El País. 2019. Available online: https://resultados.elpais.com/ elecciones/2019/municipales/05/38/38.html (accessed on 5 January 2022).

109. Reverón, E. El edil de Urbanismo de Santa Cruz insta al Gobierno de Canarias a desmantelar El Tanque. El Día 2021. Available online: https: / / www.eldia.es / santa-cruz-de-tenerife/2021/10/18/edil-urbanismo-santa-cruz-insta-58476282.html (accessed on 5 January 2021).

110. Arencibia de Torres, J. Refinería de Tenerife, 1930-2005: 75 Años de Historia; CEPSA: Santa Cruz de Tenerife, Spain, 2005.

111. Díaz Rodríguez, M.d.C.; García Herrera, L.M.; Armas Díaz, A. Puertos y espacios públicos renovados: El puerto de Santa Cruz de Tenerife. In Proceedings of the XVIII Coloquio de Historia Canario-Americana, Las Palmas de Gran Canaria, Spain, 13-17 October 2008; pp. 914-922.

112. INE-Instituto Nacional de Estadística. Hogares por Régimen de Tenencia de la Vivienda y Comunidades Autónomas. Available online: https:/ / www.ine.es/dyngs/INEbase/es / categoria.htm?c=Estadistica_P\&cid=1254735570688 (accessed on 7 May 2020).

113. Torres, N. El PSOE sigue adelante con la denuncia del Santa Cruz Verde 2030. Diario de Avisos 2018. Available online: https:/ / diariodeavisos.elespanol.com/2018/12/el-psoe-sigue-adelante-con-la-denuncia-del-santa-cruz-verde-2030/ (accessed on 7 December 2020).

114. Gobierno de Canarias. Plan de Calidad del Aire de la Aglomeración Santa Cruz de Tenerife-San Cristobal de la Laguna, por Dióxido de Azufre. Available online: http:/ /www.gobiernodecanarias.org/cptss/sostenibilidad/temas/planificacion-ambiental/ planes_calidad_aire/ (accessed on 18 November 2019).

115. Reverón, E. El Gobierno de Canarias Anuncia que Cepsa Desmantelará la Refinería en 2022. El Día. 2021. Available online: https: / / www.eldia.es / santa-cruz-de-tenerife/2021/05/12/gobierno-anuncia-cepsa-desmantelara-refineria-51704906.html (accessed on 7 February 2022).

116. Armas Díaz, A. Reestructuración urbana y producción de imagen: Los espacios públicos en Santa Cruz de Tenerife. Ph.D. Thesis, Universidad de la Laguna, Santa Cruz de Tenerife, Spain, 2016.

117. Strauch, L.; Takano, G.; Hordijk, M. Mixed-use spaces and mixed social responses: Popular resistance to a megaproject in Central Lima, Peru. Habitat Int. 2015, 45, 177-184. [CrossRef]

118. Sutherland, C.; Sim, V.; Scott, D. Contested discourses of a mixed-use megaproject: Cornubia, Durban. Habitat Int. 2015, 45, 185-195. [CrossRef]

119. Navarro-Jurado, E.; Romero-Padilla, Y.; Romero-Martínez, J.M.; Serrano-Muñoz, E.; Habegger, S.; Mora-Esteban, R. Growth machines and social movements in mature tourist destinations Costa del Sol-Málaga. J. Sustain. Tour. 2019, 27, 1786-1803. [CrossRef] 
120. Cheung, D.M.W.; Tang, B.S. Social order, leisure, or tourist attraction? The changing planning missions for waterfront space in Hong Kong. Habitat Int. 2015, 47, 231-240. [CrossRef]

121. Curran, W. 'From the Frying Pan to the Oven': Gentrification and the Experience of Industrial Displacement in Williamsburg, Brooklyn. Urban Stud. 2007, 44, 1427-1440. [CrossRef]

122. García Herrera, L.M.; Sabaté Bel, F. Global Geopolitics and Local Geoeconomics in Northwest Africa: The Industrial Port of Granadilla (Canary Islands, Spain). Geopolitics 2009, 14, 589-603. [CrossRef]

123. Mathews, V. Lofts in translation: Gentrification in the Warehouse District, Regina, Saskatchewan. Can. Geogr. /Le Géographe Can. 2019, 63, 284-296. [CrossRef]

124. Giloth, R.; Betancur, J. Where Downtown Meets Neighborhood: Industrial Displacement in Chicago, 1978-1987. J. Am. Plan. Assoc. 1988, 54, 279-290. [CrossRef]

125. Zuk, M.; Bierbaum, A.; Chapple, K.; Gorska, K.; Loukaitou-Sideris, A. Gentrification, Displacement, and the Role of Public Investment. J. Plan. Lit. 2018, 33, 31-44. [CrossRef]

126. Marcuse, P. Gentrification, Abandonment, and Displacement: Connections, Causes, and Policy Responses in New York City. Wash. Univ. J. Urban Contemp. Law 1985, 28, 195-240.

127. Majoor, S. The Disconnected Innovation of New Urbanity in Zuidas Amsterdam, Ørestad Copenhagen and Forum Barcelona. Eur. Plan. Stud. 2009, 17, 1379-1403. [CrossRef]

128. Dziomba, M. Städtebauliche Grossprojekte der Urbanen Renaissance. Projektziele im Spannungsfeld zwischen öffentlicher Steuerung und Immobilienmarktmechanismen. disP-Plan. Rev. 2007, 43, 12-24. [CrossRef]

129. Marshall, R. Emerging Urbanity: Global Urban Projects in the Asia Pacific Rim; Spon Press: London, UK; New York, NY, USA, 2003.

130. Hanakata, N.; Gasco, A. The Grand Projet politics of an urban age: Urban megaprojects in Asia and Europe. Palgrave Commun. 2018, 4, 86. [CrossRef]

131. Bornstein, L. Mega-projects, city-building and community benefits. City Cult. Soc. 2010, 1, 199-206. [CrossRef]

132. Kleibert, J.M.; Kippers, L. Living the good life? The rise of urban mixed-use enclaves in Metro Manila. Urban Geogr. 2016, 37, 373-395. [CrossRef] 